\title{
Simple Market Timing with Moving Averages
}

Instituto

Complutense

de Análisis

Económico

\section{Jukka Ilomäki}

Faculty of Management University of Tampere Finland

\section{Hannu Laurila}

Faculty of Management University of Tampere Finland

\author{
Michael McAleer \\ Department of Finance Asia University, Taiwan and \\ Discipline of Business Analytics \\ University of Sydney Business School, Australia and \\ Econometric Institute, Erasmus School of Economics \\ Erasmus University Rotterdam, The Netherlands and \\ Department of Economic Analysis and ICAE \\ Complutense University of Madrid, Spain and \\ Institute of Advanced Sciences Yokohama National University, Japan
}

\begin{abstract}
Consider using the simple moving average (MA) rule of Gartley (1935) to determine when to buy stocks, and when to sell them and switch to the risk-free rate. In comparison, how might the performance be affected if the frequency is changed to the use of MA calculations? The empirical results show that, on average, the lower is the frequency, the higher are average daily returns, even though the volatility is virtually unchanged when the frequency is lower. The volatility from the highest to the lowest frequency is about $30 \%$ lower as compared with the buy-and-hold strategy volatility, but the average returns approach the buy-and-hold returns when frequency is lower. The $30 \%$ reduction in volatility appears if we invest randomly half the time in stock markets and half in the risk-free rate.
\end{abstract}

Keywords Market timing, Moving averages, Risk-free rate, Returns and volatility

JEL Classification G32, C58, C22, C41, D23

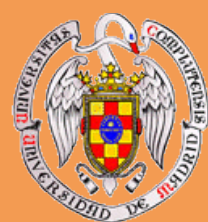

UNIVERSIDAD

COMPLUTENSE

MADRID

ISSN: 2341-2356

WEB DE LA COEECCIÓN: http://www.ucm.es/fundamentos-analisis-economico2/documentos-de-trabajo-del-icaeWorking papers are in draft form and are distributed for discussion. It may not be reproduced without permission of the author/s.

\section{Working Paper no 1814 \\ May, 2018}




\title{
Simple Market Timing with Moving Averages*
}

\author{
Jukka Ilomäki
}

Faculty of Management

University of Tampere

Finland

\section{Hannu Laurila}

Faculty of Management

University of Tampere

Finland

\section{Michael McAleer}

Department of Finance

Asia University, Taiwan

and

Discipline of Business Analytics

University of Sydney Business School, Australia

and

Econometric Institute, Erasmus School of Economics

Erasmus University Rotterdam, The Netherlands

and

Department of Economic Analysis and ICAE

Complutense University of Madrid, Spain

and

Institute of Advanced Sciences

Yokohama National University, Japan

May 2018

* For financial support, the third author acknowledges the Australian Research Council and the Ministry of Science and Technology (MOST), Taiwan.

Corresponding author: hannu.laurila@uta.fi 


\begin{abstract}
Consider using the simple moving average (MA) rule of Gartley (1935) to determine when to buy stocks, and when to sell them and switch to the risk-free rate. In comparison, how might the performance be affected if the frequency is changed to the use of MA calculations? The empirical results show that, on average, the lower is the frequency, the higher are average daily returns, even though the volatility is virtually unchanged when the frequency is lower. The volatility from the highest to the lowest frequency is about 30\% lower as compared with the buy-and-hold strategy volatility, but the average returns approach the buy-and-hold returns when frequency is lower. The $30 \%$ reduction in volatility appears if we invest randomly half the time in stock markets and half in the risk-free rate.
\end{abstract}

Keywords: Market timing, Moving averages, Risk-free rate, Returns and volatility.

JEL: G32, C58, C22, C41, D23. 


\section{Introduction}

According to the standard investing separation theorem of Tobin (1958), investors allocate investments between risk-free and risky assets. If the risk-free rate is low (high), the investors shift their wealth to (from) the risky assets. Fama (1972) divides forecasters into two categories, namely macro forecasters (or market timers) and micro forecasters (or security analysts), who try to forecast individual stock returns relative to the market returns.

Merton (1981) defines a market timer to forecast when stocks will outperform (underperform) the risk-free asset, indicating that, when $r_{t}^{m}>r_{t}^{f} \quad\left(r_{t}^{m}<r_{t}^{f}\right)$, where $r_{t}^{m}$ is average stock market returns, $r_{t}^{f}$ is the risk-free asset, $r_{t}^{i}=r_{t}^{f}+\beta^{i}\left(r_{t}^{m}-r_{t}^{f}\right)+\varepsilon_{t}^{i}, r_{t}^{i}$ is the return for individual stock $i$ included in the market portfolio $m, \beta^{i}$ is a positive parameter, and $E\left[\varepsilon_{t}^{i} \mid r_{t}^{m}\right]=E\left[\varepsilon_{t}^{i}\right]$. That is, a market timer only forecasts the statistical properties of $r_{t}^{m}-r_{t}^{f}$, indicating that their forecasts contain only the differential performance among individual stocks arising from systematic risk in the markets.

Merton (1981) shows theoretically that when investors have heterogeneous beliefs and imperfect information, the value of a random market timing forecast is zero, and if the forecast variable is distributed independently or the forecast is based on public information, its value is zero, too. In fact, Merton shows that the maximum value of skilled market timing is the value of the protective put against buy-and-hold strategy.

Henriksson and Merton (1981) present an empirical procedure whereby correct forecasts can be analyzed statistically. However, if it is assumed that $\varepsilon_{t}^{i}$ follows an approximate normal distribution, this leads to the CAPM of Sharpe (1964) and Lintner (1965).

We use a simple MA rule for the timing aspect for individual Dow Jones Industrial Average (DJIA) stocks with different frequencies. Zhu and Zhou (2009) show analytically that MA trading rules, as a part of asset allocation rules, can outperform standard allocation rules when stock returns are partly forecastable. The standard rule 
means investing a fixed proportion of wealth in risky assets and the rest in risk-free assets, with the ratio determined by the risk tolerance of an investor.

This is the well-known reward/risk (or mean-variance) principle in the spirit of Markowitz (1952), Tobin (1958) and Sharpe (1964). Zhu and Zhou (2009) argue that the fixed allocation rule is not optimal if returns are forecastable by using the MA rule. Therefore, assuming that risk tolerance and the forecast performance of stock market returns are constant, the linear combination rule means that, when the MA rule suggests an uptrend (downtrend), the rule suggests that the total weight should be allocated to stock markets (the risk-free rate).

The empirical findings suggest a low volatility anomaly that might be explained by investors' affection to high volatility, as suggested by Baker et al. (2011) and noted in Ang et al. (2009). On the other hand, the reported predictability of risk premia (see, for example, Cochrane 2008, and Fama 2014) can explain why, for instance, MA rules forecast better than using random highs and lows in the stock market (as noted in Jagannathan and Korajczyck 2017). The topic is important as Friesen and Sapp (2007), among others, report that mutual fund investors had negative outcomes, on average, in their timing to invest and withdraw cash from US mutual funds from 1991 to 2004. Munoz and Vicente (2018) report similar results with more recent data in US markets.

The plan of the remainder of the paper is as follows. Section 2 provides a literature review, and alternative model specifications are presented in Section 3. The empirical analysis is conducted in Section 4, while Section 5 gives some concluding comments.

\section{Literature Review}

In efficient markets, investors earn above average returns only by taking above average risks (Malkiel 2003). Samuelson (1998) conforms with Fama (1972) by noting that market efficiency can be divided into micro and macro efficiency. The former concerns the relative pricing of individual stocks, and the latter, for markets as a whole. The CAPM by Sharpe (1964), and Lintner (1965) argues that beta is a proper definition for systematic risk for stock $i$, if unexplained changes in risk adjusted returns for the stock follow approximately normal distribution with zero mean. 
Black (1972) states that the slope of the security market line (SML) is flatter if there exists restrictions in borrowing, that is, leverage constraints in the model. Starting from Black et al. (1972), many studies have reported that the security market line is too flat in US stocks compared with the SML suggested by the CAPM version of Sharpe and Lintner.

Ang et al. (2009), Baker et al. (2014), and Frazzini and Pedersen (2014) find that lowbeta stocks outperform high-beta stocks statistically significantly. In fact, Frazzini and Pedersen report that significant excess profits in US stocks can be achieved by shorting high-beta stocks and buying low-beta stocks with leverage, but that leverage constraints make them dissappear. Using Black (1972), investors often have leverage constraints, thereby making them place too much weight on risky stocks, which results in lower required return for high-beta stocks than would be justified by the Sharpe-Lintner CAPM.

Markowitz (1952) defines portfolio risk simply as the volatility of porfolio returns. Clarke et al. (2010) find that the volatility of stock returns contains potentially an additional risk factor with respect to systematic risk that can be defined in the betas of CAPM by Sharpe and Lintner. Moreover, Ang et al. (2009) report that the total volatility of international stock market returns is highly correlated with US stock returns, thereby suggesting a common risk factor for US stocks.

Baker et al. (2011) suggest that the low-volatility anomaly is due to investor irrational behaviour, mainly because an average fund manager seeks to beat the buy-and hold strategy by overinvesting in high-beta stocks. The explanations include preference for lotteries (Barberis and Huang 2008; Kumar 2009; Bali et al. 2011), overconfidence (Ben-David et al. 2013), and representativeness (Daniel and Titman 2006)), which means that people assess the probability of a state of the world based on how typical of that state the evidence seems to be (Kahneman and Tversky 1974).

Baker and Wurgler (2015) argue that the anomality is also related to the limits of arbitrage. In fact, the extra costs of shorting prevents to take advantage of overpricing (Hong and Sraer 2016). More importantly, Li et al. (2016) report that the excess returns of low-beta portfolios are due to mispricing in US stocks, indicating that the lowvolatility anomaly does not exist because of systematic risk by some rational, stock 
specific volatility risk factor. They tested the low-volatility anomaly with monthly data from January 1963 to December 2011 in NYSE, NASDAQ, and AMEX stocks.

Market timing is closely related to technical trading rules. Brown and Jennings (1987) show theoretically that using past prices (like the MA rule in Gartley (1935)) has value for investors, if equilibrium prices are not fully revealing, and signals from past prices have some forecasting qualities. More importantly, Zhu and Zhou (2009) indicate that the MA rules are particularly useful for asset allocation purposes among risk averse investors, when markets are forecastable (quality of signal).

Moskowitz et al. (2012) argue that there are significant time series momentum (TSM) effects in financial markets that are not related to the cross-sectional momentum effect (Jegadeesh and Titman 1993). However, TSM is closely related to MA rules, since it gives a buy (sell) signal according to some historical price reference points, whereas MA rules give a buy (sell) signal, when the current price moves above (below) the historical average of the chosen calculated rolling window measure.

Starting from LeRoy (1973) and Lucas (1978), the literature in financial economics states that financial markets returns in efficient markets are partly forecastable, when investors are risk averse. This leads to the time-varying risk premia of investors, as noted by Fama (2014). For example, Campbell and Cochrane (1999) present a consumption-based model, which indicates that when the markets are in recession (boom), risk averse investors require larger (smaller) risk premium for risky assets. More importantly, Cochrane (2008) notes that the forecastability of excess returns may lead to successful market timing rules.

Brock et al. (1992) test different MA lag rules for US stock markets, and find that they gain profits compared with holding cash. On the other hand, Sullivan et al. (1999) find that MA rules do not outperform the buy-and-hold strategy, if transaction costs are accounted for. Allen and Karjalainen (1999) use a genetic algorithm to develop the best ex-ante technical trading rule model using US data, and find some evidence of outperforming the buy-and-hold strategy. Lo et al. (2000) find that risk averse investors benefit from technical trading rules because they reduce volatility of the portfolio without giving up much returns when compared against the buy-and-hold strategy. 
More recently, Neely et al. (2014) use monthly data from January 1951 to December 2011, and report that MA rules forecast the risk premia in US stock markets statistically significantly. Marshall et al. (2017) find that MA rules give an earlier signal than TSM, suggesting better returns for MA rules, but they both work best with large market value stocks.

Moskowitz et al. (2012) use monthly data from January 1965 to December 2009, and report that TSM provides significant positive excess returns in futures markets. However, Kim et al. (2016) report that these positive excess returns produced by TSM are due to the volatility scaling factor used by Moskowitz et. al. (2012).

\section{Model Specifications}

Consider an overlapping generation economy with a continuum of young and old investors $[0,1]$. A young risk-averse investor $j$ invests their initial wealth, $w_{t}^{j}$, in infinitely lived risky assets $i=1,2, \ldots . . I$, and in risk-free assets that produce the riskfree rate of return, $r^{f}$. A risky asset $i$ pays dividend $D_{t}^{i}$, and has $x_{i}^{s}$ outstanding. Assuming exogenous prosesses throughout, the aggregate dividend is $D_{t}$.

A young investor $j$ maximizes their utility from old time consumption through optimal allocation of initial resources, $w_{t}^{j}$, between risky and risk-free assets:

$\max x_{t}^{j}\left(\frac{E_{t}\left(P_{t+1}+D_{t+1}\right)}{P_{t}}-\left(1+r^{f}\right)\right)-\frac{v^{j}}{2} x^{j^{2}} \sigma^{2}$

s.t.

$x_{t}^{j} P_{t} \leq w_{t}^{j}$

where $E_{t}$ is the expectations operator, $P_{t}$ is the price of one share of aggregate stock, $v^{j}$ is a constant risk-aversion parameter for investor $j, \sigma^{2}$ is the variance of returns for the aggregate stock, and $x_{t}^{j}$ is the demand of risky assets for an investor $j$. The first-order condition is: 
$\frac{E_{t}\left(P_{t+1}+D_{t+1}\right)}{P_{t}}-\left(1+r^{f}\right)-v^{j} x_{t}^{j} \sigma^{2}=0$,

which results in optimal demand for the risky assets:

$$
x_{t}^{j}=\frac{E_{t}\left(\left(P_{t+1}+D_{t+1}\right) / P_{t}\right)-\left(1+r^{f}\right)}{v^{j} \sigma_{i}^{2}} .
$$

Suppose that an investor $j$ is a macro forecaster who allocates their initial wealth, $w_{t}^{j}$, between risky stocks and risk-free assets according to their forecast about the return of the risky alternative. Then, equation (1) says that the investor invests in the risky stocks only if the numerator on the right hand side is positive.

\section{Empirical Analysis}

This section presents the empirical results from seven frequencies for the (MA) trendchasing rules. The data consist of 29 companies included in the Dow Jones Industrial Average (DJIA) index in January 2018. The trading data (daily closing prices) cover 30 years from 1 January 1988 to 31 December 2017. Choosing the current DJIA companies for the last 30 years creates a "survivor bias" in the buy-and-hold results. However, this should not be an issue as we intend to compare the performance of the alternative MA frequency rules.

The rolling window is 200 trading days. The first rule is to calculate MA in every trading day; the second frequency takes into account every 5th trading day (thereby providing a proxy for the weekly rule); the third frequency takes into account every 20th trading day (proxy for the monthly rule); the fourth rule is to calculate MA for every 40th trading day (proxy for every other month); the fifth rule takes into account every 60th trading day (proxy for every third month); the sixth rule takes into account every 80th trading day (proxy for every fourth month); and the seventh rule takes into account every 100th trading day (proxy for every fifth month). 
For the 29 DJIA companies, 26 of them have daily stock data available from 27 March 1987, thereby giving 4 January 1988 as the first trading day. The data for Cisco are available from 12 February 1990, for Goldman Sachs from 4 May 1999, and for Visa from 19 March 2008. There are 217569 observations of daily returns from DJIA stocks. Thus, there are 217569 × $9=1958121$ daily returns for the first three frequencies (rules), $217569 \times 4=870276$ daily returns for the fourth rule, $217569 \times 3$ $=652707$ daily returns for the fifth rule, $217569 \times 2=435138$ daily returns for the sixth rule, and 217569 daily returns for the seventh rule.

The trading rule for all cases is to use a simple crossover rule. When the trend-chasing MA turns lower (higher) than the current daily closing price, we invest the stock (threemonth US Treasury Bills) at the closing price of the next trading day. Thus, the trading rule provides a market timing strategy where we invest all wealth either in stocks (separately, every stock included in DJIA), or to the risk-free asset (three-month U.S. Treasury bill), where the moving average rule advices the timing.

At the first frequency (every trading day), we calculate daily returns for MA200, MA180, MA160, MA140, MA120, MA100, MA80, MA60, and MA40. For example, MA200 is calculated as:

$\left(\frac{P_{t-1}+P_{t-2}+\ldots+P_{t-200}}{200}\right)=X_{t-1}$.

At the lowest frequency, where every 100th daily observation is counted, MAC2 is calculated as:

$$
\left(\frac{P_{t-1}+P_{t-100}}{2}\right)=X_{t-1}
$$

If $X_{t-1}<P_{t-1}$, we buy the stock at the closing price, $P_{t}$, thereby giving daily returns as 


$$
R_{t+1}=\ln \left(\frac{P_{t+1}}{P_{t}}\right)
$$

Tables 1-7 in Appendix 1 show that the annualized average log returns of MA200 MA40 are $\mathbf{+ 0 . 0 5 3}$ after transaction costs (with $0.1 \%$ per change of position). Recall that there are 200 closing day prices in the rolling window MA200, whereas MA40 means that there are 40 closing day prices in the window. The respective log returns for MAW40-MAW8 (weekly) are $\mathbf{+ 0 . 0 6 3}$; for MA10 - MA2 (monthly) $+\mathbf{0 . 0 7 1}$; for MAD5 - MAD2 (every other month) $+\mathbf{+ 0 . 0 7 8}$; for MAT4 - MAT2 (every third month)+0.084, for MAQ3 - MAQ2 (every fourth month) +0.094; and for MAC2 (every fifth month) $\mathbf{+ 0 . 0 8 8}$ after transaction costs.

Tables 1-7 show that, as the frequency decreases until every fourth month frequency (MAQ3 - MAQ2), average returns tend to increase, and decrease thereafter. In comparison, the biased buy-and-hold strategy produces $+\mathbf{+ 0 . 1 1 7}$ with equal weights among all DJIA stocks, and with $\mathbf{0 . 2 9 5}$ annual volatility. A random investment (half the time in the risk-free rate, and half in the equally weighted portfolio from 4 January 1988) produces $(0.117 * 0.5+0.022 * 0.5)=\mathbf{+ 0 . 0 7 0}$ annually, on average, with $(1-\sqrt{0.5}=0.293)=29.3 \%$ reduction in volatility, indicating $\mathbf{0 . 2 0 9}$ annual volatility for that portfolio.

The data are dividend excluded, but the average annual dividend yield in DJIA stocks over the last thirty years has been +0.026 , so that the biased buy and hold strategy produces +0.143 annually with equal weights among DJIA stocks before taxes. Thus, the random investment strategy produces +0.083 annually, with survivor bias.

Apppendix 1 (that is, the second column of Tables 1-7) also reports the annualized average log returns calculated in the largest sample (full 200 observations) in every category: MA200 +0.065; MAW40 +0.073; MA10 +0.079; MAD5 +0.083; MAT4 $\mathbf{+ 0 . 0 8 9}$; MAQ3 +0.091; and MAC2 +0.088 after transaction costs and before dividends. Adding +0.013 produces after dividends and before taxes: MA200 +0.078; MAW40 +0.086; MA10 +0.092; MAD5 +0.096; MAT4 +0.102; MAQ3 +0.104; and MAC2 
$\mathbf{+ 0 . 1 0 1}$. These results imply that starting from every fifth trading day frequency, a macro forecaster beats the buy and hold strategy in returns.

Figure 1 below illustrates the effects of frequency on the returns to volatility ratio (the second column in Tables 1-7).

\section{$<$ Figure 1 goes here >}

In Figure 1, the straight line illustrates the return to volatility ratio of portfolios, where wealth is randomly invested in combinations of the three-month Treasury Bill (risk-free rate), with stocks included in the DJIA between 4 January 1988 and 31 December 2017. The red crosses represent the average return/volatility points calculated in the 200-day rolling window with the following frequencies: daily, every five days, every 20 days, every 40 days, every 60 days, every 80 days, and every 100 days (with only the most observations in each frequency giving 200, 40, 10, 5, 4, 3, and 2 observations). The red crosses plot a convex curve that deviates increasingly from the straight return to volatility ratio line, thereby symbolizing superior portfolio efficiency.

Tables 8-14 in Appendix 2 show that the annualized volatility of daily returns read, on average: MA200-MA40 0.2044; MAW40-MAW8 0.205; MA10-MA2 0.2091; MAD5MAD2 0.213; MAT4-MAT2 0.219; MAQ3-MAQ2 0.221; and MAC2 0.218. Thus, there is virtually no difference between the MA frequencies, while the biased buy-andhold strategy produces $\mathbf{0 . 2 9 5}$.

Figure 1 presents the volatilities calculated in the largest sample (full 200 day rolling window in every category, the second column in Tables 8-14). They read MA200 0.207; MAW40 0.208; MA10 0.211; MAD5 0.213; MAT4 0.218; MAQ3 0.215; and MAC2 0.218 after transaction costs. Investing randomly half of the time in the risk-free rate and the other half in the equally weighted portfolio, produces $\mathbf{0 . 2 0 9}$. Thus, the difference between the annual volatilities produced in profitable market timing MA rules (MA10 - MAC2) and random market timing (half and half) ranges from $\mathbf{0 . 0 0 9}$ to 0.002 . 
In Figure 2, the straight line again presents the return to volatility ratio of portfolios with random investment in the risk-free rate and the stocks in DJIA between 4 January 1988 and 31 December 2017. The red crosses plot the average return to volatility ratios, calculated by using a 200 day rolling window, with the following frequencies: daily, every five days, every 20 days, every 40 days, every 60 days, every 80 days, and every 100 days. The the averages of every lag are reported in Tables 1-14, Appendices 1 and 2. Thus, all daily returns from Tables 1-14 are included.

Comparing Figures 1 and 2, it is clear that using the whole 200 daily observation windows in the MA rules produces more efficient results in market timing. That is, comparing the products of shorter and longer MA rule rolling windows, say, the last two monthly observations compared with ten monthly observations, average realized returns drop from $\mathbf{+ 0 . 0 7 9}$ to $\mathbf{+ 0 . 0 5 9}$ before dividends, while volatility remains approximately unchanged (from 0.211 to 0.207). This suggests that, in both cases, about half and half is invested in the equally-weighted DJIA portfolios and in the riskfree rate, and the MA rules adivice the timing. More importantly, Tables 8-14 in Appendix 2 show that the range in volatilities with all MA rules varies between 0.202 0.227 (with 0.02 difference), whereas Tables 1-7 in Appendix 1 show that realized returns vary between $0.096-0.033$ before dividends (with 0.063 difference).

These results indicate that a macro market timing with 200 days rolling window produces a reduction in volatility from $\mathbf{0 . 2 9 5}$ (the buy-and hold) to between 0.207 0.218 , but the average annualized returns (dividends included) tend to rise as the MA frequency falls ( +0.078 with all 200 observations to +0.104 with every fourth month observations). Thus, the results indicate that MA market timing finds long term stochastic trends more efficiently than short term stochastic trends.

The Sharpe ratio of random market timing (half and half) with dividends is $\mathbf{0 . 2 9 2}$; for MA200 0.271; for MAW40 0.308; for MA10 0.332; for the MAD5 0.347; for MAT4 0.370; for MAQ3 $\mathbf{0 . 3 8 1}$; and for MAC2 it is $\mathbf{0 . 3 6 2}$.

\section{< Figure 3 goes here >}


Figure 3 shows that when the volatility changes $1 \%$ in the DJIA stocks, then the average returns change is $0.39 \%$. Figures 1 and 2 suggest that the theoretical change should be such that when the volatility changes $1 \%$, then the average returns change is $0.50 \%$, suggesting a flatter SML line in the data. This suggests strongly that DJIA investors have overweight high-beta stocks in the last 30 years.

It is obvious that transaction costs are crucial in MA performance. In the above calculations, the transaction costs are $0.1 \%$ per transaction from current wealth. Tables 15 and 16 in Appendix 3 report the transaction costs for the MA200-MA40 and MA10MA2 rules. In the MA200-MA40 rules, the average annualized transaction costs are 0.0133, such that the rules have about 13 changes in positions per year. Meanwhile, for the MA10-MA2 rules, the average annualized transaction costs are $\mathbf{0 . 0 0 3 2}$, suggesting about 3 changes in positions per year.

Allen and Karjalainen (1999) give reasons for a cost of $0.2 \%$ per transaction in their sample, but since technological progress has reduced transaction costs since the midnineties, $0.1 \%$ per tranction should be fair, on average. Nevertheless, a trial with $0.2 \%$ transaction costs shows that, for example, the average annualized daily returns become 0.0403 for the MA200-MA40 rules, and 0.0674 for the MA10-MA2 rules. Note that the returns grow 67\%, on average, for the MA10-MA2 rules (with about the same volatility) compared with costs of $0.1 \%$ per transaction.

Note that the model prohibits short selling since we have only long positions in stocks or investing in the risk-free rate. Then the limits of arbitrage argument of Baker et al. (2015) are consistent with our results.

\section{Concluding Remarks}

The analysis suggests that a macro forecaster can obtain higher returns with equal volatility (30 \% below that of the buy-and-hold strategy) by reducing the frequency used in MA rules. The return to volatility ratio for risk-averse investors with MA market timing significantly outperforms the random benchmark strategy, when the frequency in 
the MA rules is reduced. This indicates that the forecasts are more accurate the longer is the time frame.

The results suggest that a flatter SML in the CAPM can be followed by the irrational preference of investors in high-beta stocks, as suggested by Baker et al. (2011) and Li et al. (2016), since the empirically efficient frontier of portfolios becomes flatter than the theoretically efficient SML (random timing) (see Figure 1). In other words, the empirical results suggests that market timing with the few past obervations (for example, every fourth month) in the past 200 rolling window daily prices, have produced significantly better returns to risk ratio for the portfolio of DJIA equally weighted stocks in the past 30 years than random timing. The finding points to the lowvolatility anomaly.

One explanation for the results is that they are due to time-varying risk premiums. This is emphasized by Neely et al. (2014), who claim that MA rules, in effect, forecast changes in the risk premium. If the results are rational products of time-varying risk premiums, the results suggest that investor sensitivity to risk must be extremely high, and their risk premium is larger (smaller) in downs (ups), as suggested by Campbell and Cochrane (1999). As volatility rises (decreases), usually in downs (ups), the results suggest that when volatility is high, investors as a group tolerate significantly more risk (that is, volatility) than in calmer periods.

Consider the following numerical example: Assume that the risk premium is 0.08 in volatile downs, and 0.04 in calm ups, and the variance of returns is 0.03 in downs and 0.09 in ups. Then the risk aversion coefficient must be 0.89 in volatile down periods, and 1.33 in calm up periods. As market timing with MA rules works better in longer periods with few obervations, it seems to be more accurate in longer stochastic (up or down) trends. 


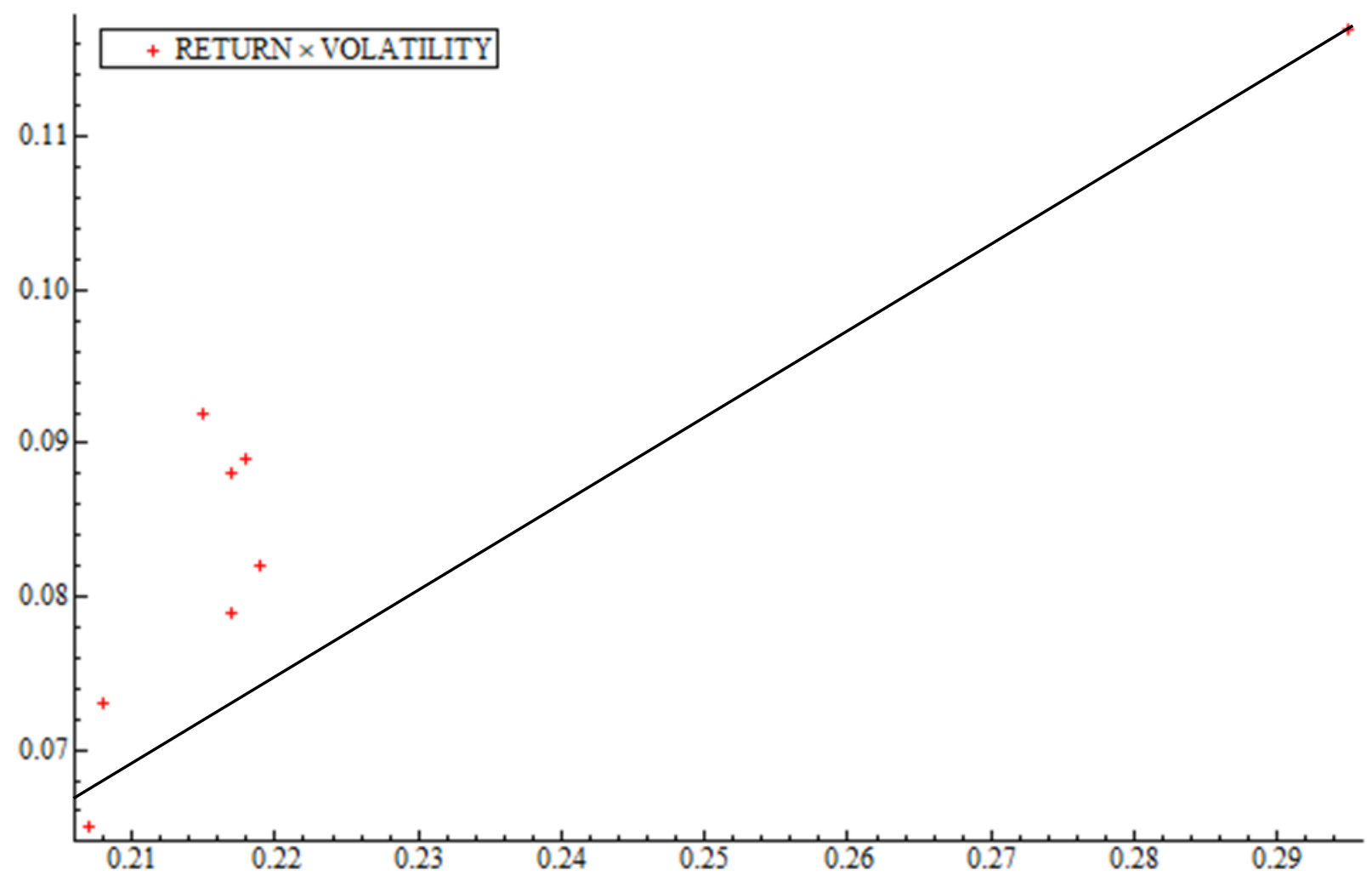

Figure 1: Returns to volatity ratio in MA200, MAW40, MA10, MAD5, MAT4, MAQ3, MAC2, and the theoretical random timing efficient SML 


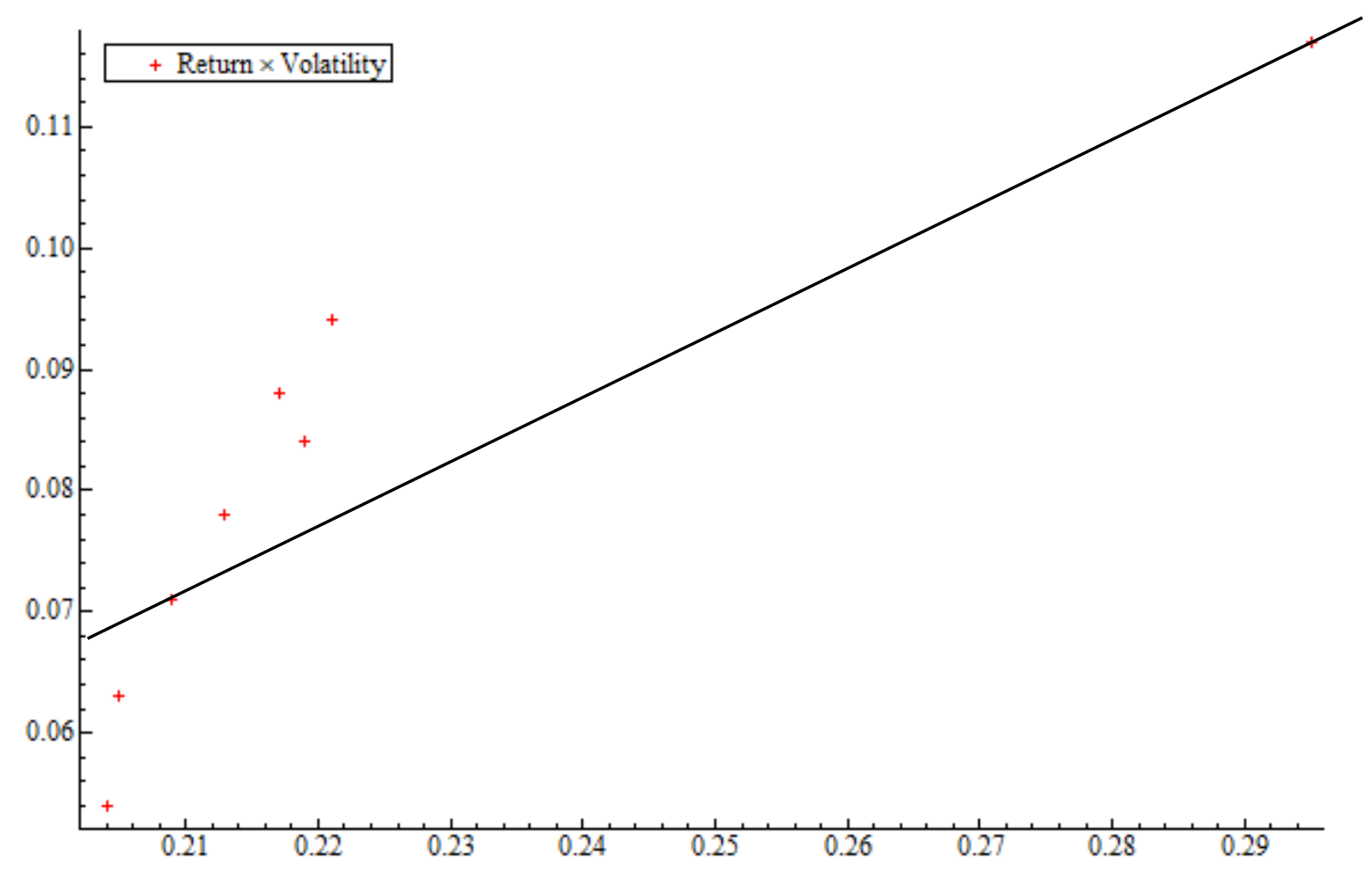

Figure 2: Returns to volatity ratio in MA200-MA40, MAW40-MAW8, MA10-

MA2, MAD5-MAD2, MAT4-MAT2, MAQ3-MAQ2, MAC2, and the theoretical random timing efficient SML 


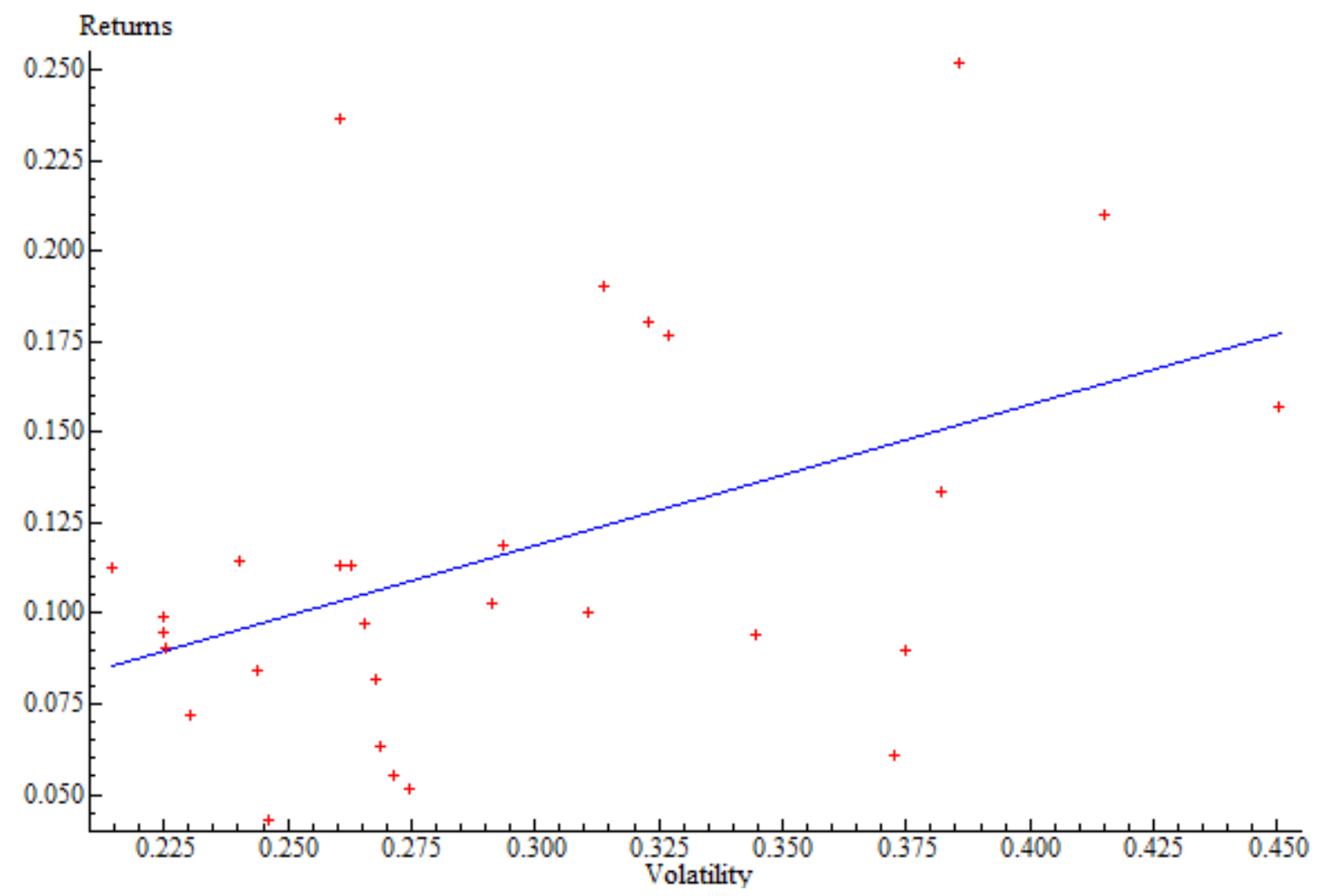

Figure 3: Returns to the volatility ratio in current DJIA stocks in annual averages from 4 January 1988 to 31 December 2017 


\section{References}

Allen, F., Karjalainen, R. (1999), Using genetic algorithms to find technical trading rules, Journal of Financial Economics 51: 245-271.

Ang, A., Hodrick, R., Xing, Y., Zhang, X. (2009), High idiosyncratic volatility and low returns: International and further U.S. evidence, Journal of Financial Economics 61: 123.

Baker, M., Bradley, B., Wurgler, J. (2011a), Benchmark as limits to arbitrage: Understanding the low-volatility anomaly, Financial Analysts Journal 67: 1-15.

Baker, M., Bradley, B., Taliaferro, R. (2014), The Low-risk anomaly: a decomposition into micro and macro effects, Financial Analysts Journal 70: 45-58.

Baker, M., Wurgler, J. (2015), Do strict requirements raise the cost of capital? Bank regulation, capital structure, and the low-risk anomaly, American Economic Review: Papers \& Proceedings 105: 315-320.

Bali, T., Cakici, N., Whitelaw, R. (2011), Maxing out: stock as lotteries and the crosssection of expected returns, Journal of Financial Economics 99: 427-446.

Barberis, N., Huang, M. (2008), Stocks as lotteries: The implications of probability weighting for security prices, American Economic Review 98: 2066-2100.

Ben-David, I., Graham, J., Harvey, C. (2013), Managerial miscalibration, Quarterly Journal of Economics 128: 1547-1584.

Black, F. (1972), Capital market equilibrium with restricted borrowing, Journal of Business 45: 444-455. 
Black, F., Jensen, M., Scholes, M. (1972), The capital asset market model: some empirical tests. In: Jensen, Studies in the theory of capital markets, Praeger, New York, 79-121.

Brock, W., Lakonishok, J., LeBaron, B. (1992), Simple technical trading rules and the stochastic properties of stock returns, Journal of Finance 47: 1731-1764.

Brown, D., Jennings, R. (1989), On technical analysis, Review of Financial Studies 2: 527-551.

Campbell, J., Cochrane, J. (1999), By force of habit: Consumption-based explanation of aggregate stock market behavior, Journal of Political Economy 107: 205-251.

Cochrane, J. (2008), The dog that did not bark: A defense of return predictability, Review of Financial Studies 21: 1533-1573.

Daniel, K., Titman, S. (2006), Market reactions to tangible and intangible information, Journal of Finance 61: 1605-1643.

Fama, E. (1972), Components on investment performance, Journal of Finance 27: 551568.

Fama, E. (2014), Two pillars of asset pricing, American Economic Review 104: 14671485.

Frazzini, A., Pedersen, L. (2014), Betting against betas, Journal of Financial Economics 111: 1-25.

Friesen, G., Sapp, T. (2007), Mutual fund flows and investor returns: An empirical examination of fund investor timing ability, Journal of Banking and Finance 31: 27962816.

Gartley, H. (1935), Profits in the Stock Markets, Washington: Lambert-Gann Publishing. 
Henriksson, R., Merton R., (1981), On market timing and investment performance II: Statistical procedures for evaluating forecasting skills, Journal of Business 54: 513-533.

Hong, H., Sraer, D., (2016), Speculative betas, Journal of Finance 71: 2095-2144.

Jagannathan, R., Korajczyk, R. (2017), Market timing. In: Guerard, Portfolio Construction, Measurement and Efficiency, Springer International Publishing Switzerland, 49-71.

Jegadeesh, N., Titman, S. (1993), Returns to buying winners selling losers: Implications for stock market efficiency, Journal of Finance 48: 65-91.

Kahneman, D., Tversky, A. (1974), Judgement under uncertainty: Heuristics and biases, Science 185: 1124-1131.

Kim, A., Tse, Y., Wald, J. (2016), Time series momentum and volatility scaling, Journal of Financial Markets 30, 103-124.

Kumar, A. (2009), Who gambles in the stock markets? Journal of Finance 64: 18891933.

LeRoy, S. (1973), Risk aversion and the martingale property of stock prices, International Economic Review 14: 436-446.

Li, X., Sullivan, R., Garcia-Feijoo, L. (2016), The low-volatility anomaly: Market evidence on systematic risk vs. mispricing, Financial Analysts Journal 72: 36-47.

Lintner, J. (1965), The valuation of risky assets and the selection of risky investments in stock portfolios and capital budgets, Review of Economics and Statistics 47, 13-37.

Lo, A., Mamaysky, H., Wang, J. (2000), Foundations of technical analysis: Computational algorithms, statistical inference, and empirical implementation, Journal of Finance 54: 1705-1770. 
Lucas, R. (1978), Asset prices in an exchange economy, Econometrica 46: 1429-1445.

Markowitz, H. (1952), Portfolio selection, Journal of Finance 7: 77-91.

Malkiel, B. (2003), The efficient market hypothesis and its critics, Journal of Economic Perspectives 17: 59-82.

Marshall, B., Nguyen, N., Visaltanachoti, N. (2017), Time series momentum and moving average trading rules, Quantitative Finance 17: 405-421.

Merton, R. (1981), On market timing and investment performance. I. An equilibrium theory of value for market forecast, Journal of Business 54: 363-406.

Moskowitz, T., Ooi, Y., Pedersen, L. (2012), Time series momentum, Journal of Financial Economics 104: 228-250.

Munoz, F., Vicente, R. (2018), Hindsight effect: What are actual cash flow timing skills of mutual fund investors?, Journal of Empirical Finance 45: 181-193.

Neely, C., Rapach, D., Tu, J., Zhou, G. (2014), Forecasting equity risk premium: The role of technical indicators, Management Science 66: 1772-1791.

Samuelson, P. (1998), Summing up on business cycles: Opening address, in Beyond Shocks; What Causes Business Cycles? Edited by J. Fuhrer and S. Schuh, Boston: Federal Reserve Bank of Boston.

Sharpe, W. (1964), Capital asset prices: A theory of market equilibrium under conditions of risk, Journal of Finance 19: 425-442.

Sullivan, R., Timmermann, A., White, H. (1999), Data-snooping, technical trading rule performance and the bootstrap, Journal of Finance 53: 1647-1691.

Tobin, J. (1958), Liquidity preference as behavior towards risk, Review of Economic Studies 67: 65-86. 
Zhu, Y., Zhou, G. (2009), Technical analysis: An asset allocation perspective on the use of moving averages, Journal of Financial Economics 91: 519-544.

\section{$\underline{\text { Appendix } 1}$}

Table 1: Annualized daily returns of MA40-MA200, average annualized returns

\begin{tabular}{|c|c|c|c|c|c|c|c|c|c|c|}
\hline & $\&$ & & & & & & & & & \\
\hline & Hold & MA200 & MA180 & MA160 & MA140 & MA120 & MA100 & MA80 & MA60 & MA40 \\
\hline$M$ & 0.090 & 0.042 & 0.034 & 0.017 & 0.015 & 0.019 & 0.014 & 0.006 & -0.009 & $6 \mathrm{E}-04$ \\
\hline merican Express & 94 & 0.035 & 0.037 & 0.039 & 0.055 & 0.039 & 0.042 & 0.043 & 0.041 & .008 \\
\hline Apple & 157 & 0.147 & 0.145 & 0.147 & 0.142 & 0.156 & 0.149 & 0.150 & 0.146 & 0.164 \\
\hline Boeing & 19 & 0.088 & 0.089 & 0.060 & 0.055 & 0.061 & 0.061 & .058 & 0.046 & 0.048 \\
\hline aterpillar & 100 & 0.075 & 0.079 & 0.058 & 0.058 & 0.049 & 0.034 & 0.028 & 0.039 & 0.025 \\
\hline Chevron & 084 & 0.005 & 0.013 & 0.002 & -0.000 & -0.000 & 0.003 & -0.01 & -0.025 & -0.05 \\
\hline Coca-Cola & 99 & 0.058 & 0.055 & 0.030 & 0.035 & 0.039 & 0.027 & 0.023 & 0.009 & 0.003 \\
\hline Walt Disne & 103 & 0.072 & 0.078 & 0.079 & 0.074 & 0.077 & 0.074 & 0.076 & 0.056 & 0.048 \\
\hline Exxon & 072 & -0.011 & -0.010 & -0.020 & -0.030 & -0.020 & -0.025 & -0.01 & -0.044 & -0.05 \\
\hline GE & 052 & 0.072 & 0.071 & 0.058 & 0.039 & 0.039 & 0.033 & 0.018 & 0.013 & $9 \mathrm{E}-04$ \\
\hline Hom & 90 & 0.125 & 0.116 & 0.102 & 0.092 & 0.087 & 0.076 & 0.067 & 0.068 & 0.058 \\
\hline IBM & 055 & 0.016 & 0.029 & 0.033 & 0.028 & 0.016 & 0.021 & 0.031 & 0.029 & 0.048 \\
\hline Intel & 34 & 0.083 & .082 & 0.083 & 0.073 & 0.091 & 0.082 & 0.080 & 0.077 & 0.078 \\
\hline Johr & 13 & 0.062 & 58 & 0.053 & 42 & 32 & 44 & 028 & 08 & -0.00 \\
\hline JP M & 090 & 0.013 & .014 & 0.003 & 0.010 & 0.017 & 0.013 & 0.031 & 0.038 & 0.025 \\
\hline McDo & 14 & 0.047 & .048 & 0.040 & 0.044 & .040 & 0.035 & 0.043 & 0.030 & 0.018 \\
\hline Merck & 63 & 0.050 & 0.048 & 0.044 & 0.032 & 0.033 & 0.029 & 0.022 & 0.016 & -0.02 \\
\hline Microsc & 180 & 0.117 & 0.128 & 0.105 & 0.102 & 0.104 & 0.095 & 0.090 & 0.070 & 0.062 \\
\hline Nike & 177 & 0.087 & .093 & 0.085 & 0.102 & 0.108 & 0.107 & 0.119 & 0.133 & 0.112 \\
\hline Pfizer & 097 & 0.059 & 0.056 & 0.043 & 0.042 & 0.052 & 0.044 & 0.040 & 0.024 & 0.009 \\
\hline Proct & 0.095 & 0.037 & 0.045 & 0.037 & 0.036 & 0.037 & 0.029 & 0.023 & 0.004 & 0.017 \\
\hline Travellers & 0.082 & 0.036 & 0.035 & 0.038 & 0.029 & 0.008 & -0.004 & $-9 E-04$ & -0.001 & 0.006 \\
\hline Unite & 0.113 & 0.051 & 0.057 & 0.046 & 0.059 & 0.057 & 0.049 & 0.049 & 0.041 & 0.017 \\
\hline United Health Group & 0.252 & 0.181 & 0.182 & 0.157 & 0.147 & 0.136 & 0.130 & 0.118 & 0.125 & 0.076 \\
\hline Verizon & 0.043 & -0.017 & -0.020 & -0.010 & -0.000 & -0.020 & -0.020 & -0.02 & -0.029 & -0.02 \\
\hline Wal-N & ك+1. & 0.019 & 0.016 & 0.010 & 0.012 & 0.012 & 0.016 & 0.012 & 0.020 & 0.024 \\
\hline Cisco & 210 & 0.198 & 0.194 & 0.210 & 0.208 & 0.198 & 0.205 & 0.152 & 0.096 & 0.085 \\
\hline Goldman Sachs & 0.061 & 0.038 & 0.029 & 0.033 & 0.038 & 0.050 & 0.057 & 0.078 & 0.076 & 0.06 \\
\hline
\end{tabular}




$\begin{array}{llllllllllll}\text { Visa } & 0.236 & 0.112 & 0.118 & 0.129 & 0.141 & 0.128 & 0.132 & 0.120 & 0.094 & 0.085 & \\ \text { Average } & \mathbf{0 . 1 1 7} & \mathbf{0 . 0 6 5} & \mathbf{0 . 0 6 6} & \mathbf{0 . 0 5 9} & \mathbf{0 . 0 5 8} & \mathbf{0 . 0 5 7} & \mathbf{0 . 0 5 3} & \mathbf{0 . 0 5} & \mathbf{0 . 0 4 1} & \mathbf{0 . 0 3 3} & \mathbf{0 . 0 5 4}\end{array}$

Table 2: Annualized daily (every fifth trading day) returns of MAW8-MAW40

( $\mathrm{W}=$ number of weeks), average annualized returns

$3 \mathrm{M}$

American Express

Apple

Boeing

Caterpillar

Chevron

Coca-Cola

Walt Disney

Exxon

GE

Home Depot

IBM

Intel

Johnson \& Johnson

JP Morgan

McDonalds

Merck

Microsoft

Nike

Pfizer

Procter \& Gamble

Travellers

United Technologies

United Health Group

Verizon

Wal-Mart

Cisco

Goldman Sachs

Visa

Average

\begin{tabular}{|c|c|c|c|c|c|c|c|c|c|}
\hline ly\&Hold & MAW40 & MAW36 & MAW32 & MAW28 & MAW24 & MAW20 & MAW16 & MAW12 & MAW8 \\
\hline 0.090 & 0.035 & 0.033 & 0.020 & 0.021 & 0.019 & 0.012 & 0.019 & 0.032 & 0.026 \\
\hline 0.094 & 0.058 & 0.053 & 0.062 & 0.063 & 0.047 & 0.046 & 0.035 & 0.034 & 0.015 \\
\hline 0.157 & 0.130 & 0.137 & 0.143 & 0.131 & 0.134 & 0.131 & 0.188 & 0.174 & 0.144 \\
\hline 0.119 & 0.089 & 0.079 & 0.075 & 0.074 & 0.080 & 0.082 & 0.066 & 0.074 & 0.076 \\
\hline 0.100 & 0.057 & 0.062 & 0.058 & 0.058 & 0.061 & 0.054 & 0.049 & 0.043 & 0.023 \\
\hline 0.084 & 0.005 & 0.015 & 3E-04 & 0.004 & 0.008 & 0.009 & 0.004 & 0.004 & -0.03 \\
\hline 0.099 & 0.055 & 0.054 & 0.054 & 0.041 & 0.054 & 0.047 & 0.047 & 0.029 & 0.011 \\
\hline 0.103 & 0.071 & 0.073 & 0.062 & 0.080 & 0.076 & 0.080 & 0.078 & 0.065 & 0.051 \\
\hline 0.072 & 0.018 & 0.016 & 0.007 & 0.008 & 0.010 & 0.013 & 0.020 & 0.011 & 0.005 \\
\hline 0.052 & 0.061 & 0.046 & 0.047 & 0.047 & 0.045 & 0.023 & 0.018 & 0.031 & 0.023 \\
\hline 0.190 & 0.135 & 0.133 & 0.124 & 0.112 & 0.110 & 0.088 & 0.076 & 0.096 & 0.077 \\
\hline 0.055 & 0.020 & 0.037 & 0.044 & 0.040 & 0.051 & 0.027 & 0.028 & 0.008 & 0.016 \\
\hline 0.134 & 0.088 & 0.091 & 0.075 & 0.061 & 0.075 & 0.073 & 0.070 & 0.076 & 0.085 \\
\hline 0.113 & 0.074 & 0.079 & 0.071 & 0.059 & 0.050 & 0.050 & 0.048 & 0.042 & 0.027 \\
\hline 0.090 & 0.040 & 0.036 & 0.027 & 0.033 & 0.033 & 0.048 & 0.051 & 0.042 & 0.020 \\
\hline 0.114 & 0.086 & 0.068 & 0.059 & 0.058 & 0.052 & 0.052 & 0.059 & 0.058 & 0.044 \\
\hline 0.063 & 0.051 & 0.039 & 0.029 & 0.034 & 0.034 & 0.030 & 0.033 & 0.024 & 0.029 \\
\hline 0.180 & 0.128 & 0.125 & 0.116 & 0.116 & 0.116 & 0.105 & 0.099 & 0.062 & 0.078 \\
\hline 0.177 & 0.087 & 0.091 & 0.098 & 0.093 & 0.087 & 0.094 & 0.102 & 0.119 & 0.091 \\
\hline 0.097 & 0.070 & 0.061 & 0.057 & 0.053 & 0.063 & 0.049 & 0.050 & 0.044 & 0.050 \\
\hline 0.095 & 0.050 & 0.044 & 0.050 & 0.051 & 0.040 & 0.043 & 0.042 & 0.031 & 0.033 \\
\hline 0.082 & 0.020 & 0.006 & 0.010 & 0.014 & 0.006 & 0.005 & 0.008 & 0.017 & 0.015 \\
\hline 0.113 & 0.071 & 0.077 & 0.062 & 0.072 & 0.071 & 0.056 & 0.061 & 0.051 & 0.053 \\
\hline 0.252 & 0.171 & 0.133 & 0.130 & 0.151 & 0.124 & 0.134 & 0.123 & 0.113 & 0.087 \\
\hline 0.043 & -0.00 & -0.01 & 0.002 & 0.006 & -0.01 & -0.01 & -0.01 & -0.009 & -0.00 \\
\hline 0.113 & 0.050 & 0.049 & 0.045 & 0.038 & 0.028 & 0.033 & 0.026 & 0.038 & 0.029 \\
\hline 0.210 & 0.209 & 0.211 & 0.219 & 0.222 & 0.219 & 0.204 & 0.164 & 0.120 & 0.094 \\
\hline 0.061 & 0.050 & 0.030 & 0.031 & 0.040 & 0.036 & 0.071 & 0.089 & 0.078 & 0.077 \\
\hline 0.236 & 0.143 & 0.142 & 0.131 & 0.171 & 0.167 & 0.159 & 0.113 & 0.119 & 0.080 \\
\hline 0.117 & 0.073 & 0.069 & 0.066 & 0.067 & 0.065 & 0.062 & 0.061 & 0.056 & 0.046 \\
\hline
\end{tabular}


Table 3: Annualized daily (every 20s trading day) returns of MA2-MA10, average annualized returns

\begin{tabular}{|c|c|c|c|c|c|c|c|c|c|c|c|}
\hline & $\begin{array}{l}\text { Buy } \\
\text { and }\end{array}$ & & & & & & & & & & \\
\hline & Hold & MA10 & MA9 & MA8 & MA7 & MA6 & MA5 & MA4 & MA3 & MA2 & \\
\hline $3 M$ & 0.090 & 0.033 & 0.035 & 0.023 & 0.023 & 0.024 & 0.023 & 0.038 & 0.021 & 0.012 & \\
\hline American Express & 0.094 & 0.086 & 0.087 & 0.091 & 0.107 & 0.088 & 0.062 & 0.062 & 0.036 & 0.038 & \\
\hline Apple & 0.157 & 0.057 & 0.069 & 0.056 & 0.076 & 0.076 & 0.094 & 0.069 & 0.099 & 0.071 & \\
\hline Boeing & 0.119 & 0.122 & 0.122 & 0.102 & 0.099 & 0.115 & 0.110 & 0.100 & 0.091 & 0.077 & \\
\hline Caterpillar & 0.100 & 0.065 & 0.062 & 0.071 & 0.083 & 0.081 & 0.063 & 0.057 & 0.009 & 0.051 & \\
\hline Chevron & 0.084 & 0.022 & 0.021 & 0.025 & 0.026 & 0.019 & 0.032 & 0.032 & 0.013 & 0.005 & \\
\hline Coca-Cola & 0.099 & 0.083 & 0.072 & 0.087 & 0.071 & 0.073 & 0.072 & 0.069 & 0.046 & 0.026 & \\
\hline Walt Disney & 0.103 & 0.061 & 0.066 & 0.073 & 0.077 & 0.071 & 0.079 & 0.081 & 0.073 & 0.057 & \\
\hline Exxon & 0.072 & 0.040 & 0.038 & 0.028 & 0.028 & 0.034 & 0.020 & 0.027 & 0.025 & 0.026 & \\
\hline GE & 0.052 & 0.079 & 0.078 & 0.080 & 0.072 & 0.070 & 0.063 & 0.018 & 0.038 & 0.037 & \\
\hline Home Depot & 0.190 & 0.126 & 0.133 & 0.134 & 0.136 & 0.120 & 0.14 & 0.119 & 0.118 & 0.110 & \\
\hline IBM & 0.055 & 0.029 & 0.033 & 0.032 & 0.038 & 0.036 & 0.026 & 0.033 & 0.026 & 0.03 & \\
\hline Intel & 0.134 & 0.079 & 0.080 & 0.096 & 0.095 & 0.085 & 0.063 & 0.082 & 0.110 & 0.116 & \\
\hline Johnson \& Johnson & 0.113 & 0.078 & 0.076 & 0.071 & 0.059 & 0.057 & 0.058 & 0.050 & 0.052 & 0.031 & \\
\hline JP Morgan & 0.090 & 0.057 & 0.051 & 0.051 & 0.063 & 0.046 & 0.070 & 0.079 & 0.067 & 0.067 & \\
\hline McDonalds & 0.114 & 0.077 & 0.077 & 0.057 & 0.055 & 0.045 & 0.056 & 0.042 & 0.045 & 0.033 & \\
\hline Merck & 0.063 & 0.069 & 0.069 & 0.054 & 0.059 & 0.05 & 0.045 & 0.027 & 0.011 & $3 E-04$ & \\
\hline Microsoft & 0.180 & 0.122 & 0.127 & 0.123 & 0.099 & 0.112 & 0.093 & 0.095 & 0.090 & 0.108 & \\
\hline Nike & 0.177 & 0.128 & 0.136 & 0.130 & 0.127 & 0.115 & 0.111 & 0.109 & 0.082 & 0.089 & \\
\hline Pfizer & 0.097 & 0.070 & 0.069 & 0.067 & 0.068 & 0.066 & 0.068 & 0.056 & 0.040 & 0.034 & \\
\hline Procter \& Gamble & 0.095 & 0.057 & 0.060 & 0.055 & 0.042 & 0.043 & 0.021 & 0.024 & 0.038 & 0.039 & \\
\hline Travellers & 0.082 & 0.045 & 0.049 & 0.047 & 0.041 & 0.034 & 0.016 & 0.009 & 0.002 & 0.017 & \\
\hline United Technologies & 0.113 & 0.064 & 0.062 & 0.074 & 0.078 & 0.063 & 0.046 & 0.037 & 0.050 & 0.050 & \\
\hline United Health Group & 0.252 & 0.158 & 0.162 & 0.167 & 0.154 & 0.168 & 0.176 & 0.174 & 0.180 & 0.158 & \\
\hline Verizon & 0.043 & 0.002 & $9 E-04$ & 0.011 & 0.017 & 0.025 & -0.00 & 0.01 & -0.00 & -0.02 & \\
\hline Wal-Mart & 0.113 & 0.046 & 0.046 & 0.040 & 0.044 & 0.032 & 0.041 & 0.037 & 0.023 & 0.038 & \\
\hline Cisco & 0.210 & 0.228 & 0.227 & 0.222 & 0.221 & 0.191 & 0.186 & 0.184 & 0.160 & 0.134 & \\
\hline Goldman Sachs & 0.061 & 0.029 & 0.030 & 0.020 & 0.052 & 0.067 & 0.065 & 0.070 & 0.041 & 0.068 & \\
\hline Visa & 0.236 & 0.171 & 0.161 & 0.162 & 0.149 & 0.122 & 0.113 & 0.115 & 0.142 & 0.097 & \\
\hline Average & 0.117 & 0.079 & 0.079 & 0.078 & 0.078 & 0.073 & 0.069 & 0.066 & 0.059 & 0.055 & 0.071 \\
\hline
\end{tabular}


Table 4: Annualized daily (every other month) returns of MAD2-MAD2 (D = every other month, and 5,4,3,2 are the numbers of observations in the rolling window), average annualized returns

\begin{tabular}{|c|c|c|c|c|c|}
\hline $3 M$ & 0.090 & 0.062 & 0.063 & 0.042 & 0.049 \\
\hline American Express & 0.094 & 0.089 & 0.098 & 0.052 & 0.041 \\
\hline Apple & 0.157 & 0.040 & 0.042 & 0.030 & 0.085 \\
\hline Boeing & 0.119 & 0.112 & 0.110 & 0.102 & 0.110 \\
\hline Caterpillar & 0.100 & 0.079 & 0.09 & 0.089 & 0.084 \\
\hline Chevron & 0.084 & 0.033 & 0.036 & 0.026 & 0.028 \\
\hline Coca-Cola & 0.099 & 0.093 & 0.102 & 0.080 & 0.078 \\
\hline Walt Disney & 0.103 & 0.068 & 0.074 & 0.080 & 0.084 \\
\hline Exxon & 0.072 & 0.022 & 0.018 & 0.010 & 0.009 \\
\hline GE & 0.052 & 0.067 & 0.066 & 0.041 & 0.033 \\
\hline Home Depot & 0.190 & 0.174 & 0.175 & 0.156 & 0.160 \\
\hline IBM & 0.055 & 0.016 & 0.023 & 0.017 & 0.021 \\
\hline Intel & 0.134 & 0.093 & 0.098 & 0.089 & 0.112 \\
\hline Johnson \& Johnson & 0.113 & 0.083 & 0.086 & 0.048 & 0.071 \\
\hline JP Morgan & 0.090 & 0.053 & 0.052 & 0.048 & 0.054 \\
\hline McDonalds & 0.114 & 0.094 & 0.098 & 0.071 & 0.070 \\
\hline Merck & 0.063 & 0.084 & 0.067 & 0.036 & 0.031 \\
\hline Microsoft & 0.180 & 0.138 & 0.136 & 0.106 & 0.088 \\
\hline Nike & 0.177 & 0.140 & 0.144 & 0.133 & 0.122 \\
\hline Pfizer & 0.097 & 0.062 & 0.051 & 0.061 & 0.059 \\
\hline Procter \& Gamble & 0.095 & 0.048 & 0.054 & 0.048 & 0.034 \\
\hline Travellers & 0.082 & 0.018 & 0.015 & 0.018 & $2 \mathrm{E}-04$ \\
\hline United Technologies & 0.113 & 0.066 & 0.073 & 0.096 & 0.060 \\
\hline United Health Group & 0.252 & 0.181 & 0.179 & 0.191 & 0.207 \\
\hline Verizon & 0.043 & -0.018 & -0.01 & -0.02 & -0.02 \\
\hline Wal-Mart & 0.113 & 0.067 & 0.065 & 0.050 & 0.061 \\
\hline Cisco & 0.210 & 0.217 & 0.226 & 0.207 & 0.196 \\
\hline Goldman Sachs & 0.061 & 0.041 & 0.059 & 0.060 & 0.039 \\
\hline Visa & 0.236 & 0.174 & 0.173 & 0.151 & 0.120 \\
\hline Average & 0.117 & 0.083 & 0.085 & 0.073 & 0.072 \\
\hline
\end{tabular}


Table 5: Annualized daily (every third month) returns of MAT2-MAT4 ( $T$ = every third month, and 4,3,2 are the numbers of observations in the rolling window), average annualized returns

\begin{tabular}{|c|c|c|c|c|}
\hline $3 M$ & 0.090 & 0.061 & 0.055 & 0.039 \\
\hline American Express & 0.094 & 0.113 & 0.091 & 0.066 \\
\hline Apple & 0.157 & 0.089 & 0.073 & 0.096 \\
\hline Boeing & 0.119 & 0.127 & 0.131 & 0.114 \\
\hline Caterpillar & 0.100 & 0.070 & 0.069 & 0.078 \\
\hline Chevron & 0.084 & 0.047 & 0.053 & 0.037 \\
\hline Coca-Cola & 0.099 & 0.077 & 0.078 & 0.072 \\
\hline Walt Disney & 0.103 & 0.043 & 0.042 & 0.068 \\
\hline Exxon & 0.072 & 0.055 & 0.049 & 0.037 \\
\hline GE & 0.052 & 0.084 & 0.080 & 0.047 \\
\hline Home Depot & 0.190 & 0.161 & 0.163 & 0.128 \\
\hline IBM & 0.055 & 0.054 & 0.048 & 0.028 \\
\hline Intel & 0.134 & 0.107 & 0.115 & 0.072 \\
\hline Johnson \& Johnson & 0.113 & 0.094 & 0.094 & 0.074 \\
\hline JP Morgan & 0.090 & 0.058 & 0.076 & 0.007 \\
\hline McDonalds & 0.114 & 0.080 & 0.082 & 0.069 \\
\hline Merck & 0.063 & 0.062 & 0.062 & 0.049 \\
\hline Microsoft & 0.180 & 0.127 & 0.128 & 0.080 \\
\hline Nike & 0.177 & 0.146 & 0.151 & 0.099 \\
\hline Pfizer & 0.097 & 0.078 & 0.070 & 0.056 \\
\hline Procter \& Gamble & 0.095 & 0.068 & 0.072 & 0.076 \\
\hline Travellers & 0.082 & 0.041 & 0.043 & 0.025 \\
\hline United Technologies & 0.113 & 0.077 & 0.089 & 0.079 \\
\hline United Health Group & 0.252 & 0.147 & 0.161 & 0.178 \\
\hline Verizon & 0.043 & -0.00 & -0.00 & -0.02 \\
\hline Wal-Mart & 0.113 & 0.081 & 0.081 & 0.083 \\
\hline Cisco & 0.210 & 0.211 & 0.217 & 0.213 \\
\hline Goldman Sachs & 0.061 & 0.044 & 0.026 & 0.030 \\
\hline Visa & 0.236 & 0.183 & 0.199 & 0.177 \\
\hline Average & 0.117 & 0.089 & 0.089 & 0.075 \\
\hline
\end{tabular}


Table 6: Annualized daily (every fourth month) returns of MAQ2-MAQ3 $(Q=$ every fourth month, and 3 and 2 are the numbers of observations in the rolling window), average annualized returns

$\begin{array}{llll} & \text { Buy\&Hold } & \text { MAQ3 } & \text { MAQ2 } \\ \text { 3M } & 0.090 & 0.056 & 0.058 \\ \text { American Express } & 0.094 & 0.089 & 0.094 \\ \text { Apple } & 0.157 & 0.094 & 0.094 \\ \text { Boeing } & 0.119 & 0.122 & 0.128 \\ \text { Caterpillar } & 0.100 & 0.064 & 0.084 \\ \text { Chevron } & 0.084 & 0.060 & 0.054 \\ \text { Coca-Cola } & 0.099 & 0.083 & 0.093 \\ \text { Walt Disney } & 0.103 & 0.061 & 0.062 \\ \text { Exxon } & 0.072 & 0.056 & 0.064 \\ \text { GE } & 0.052 & 0.069 & 0.081 \\ \text { Home Depot } & 0.190 & 0.152 & 0.157 \\ \text { IBM } & 0.055 & 0.048 & 0.031 \\ \text { Intel } & 0.134 & 0.064 & 0.070 \\ \text { Johnson \& Johnson } & 0.113 & 0.080 & 0.079 \\ \text { JP Morgan } & 0.090 & 0.085 & 0.091 \\ \text { McDonalds } & 0.114 & 0.096 & 0.112 \\ \text { Merck } & 0.063 & 0.056 & 0.061 \\ \text { Microsoft } & 0.180 & 0.143 & 0.145 \\ \text { Nike } & 0.177 & 0.181 & 0.199 \\ \text { Pfizer } & 0.097 & 0.059 & 0.045 \\ \text { Procter \& Gamble } & 0.095 & 0.073 & 0.077 \\ \text { Travellers } & 0.082 & 0.051 & 0.051 \\ \text { United Technologies } & 0.113 & 0.080 & 0.077 \\ \text { United Health Group } & 0.252 & 0.185 & 0.218 \\ \text { Verizon } & 0.043 & 0.027 & 0.023 \\ \text { Wal-Mart } & 0.113 & 0.087 & 0.076 \\ \text { Cisco } & 0.210 & 0.195 & 0.180 \\ \text { Goldman Sachs } & 0.061 & 0.042 & 0.056 \\ \text { Visa } & 0.236 & 0.195 & 0.228 \\ \text { Average } & \mathbf{0 . 1 1 7} & \mathbf{0 . 0 9 1} & \mathbf{0 . 0 9 6} \\ & & & \mathbf{0 . 0 9 4} \\ & & & \\ \text { Men } & & \end{array}$


Table 7: Annualized daily (every fifth month) returns of MAC2 (C = every fifth month, and 2 = observations accounting in the rolling window), average annualized returns

\begin{tabular}{lcc} 
& $\begin{array}{c}\text { Buy \& } \\
\text { Hold }\end{array}$ & MAC2 \\
3M & 0.090 & 0.076 \\
American Express & 0.094 & 0.088 \\
Apple & 0.157 & 0.132 \\
Boeing & 0.119 & 0.080 \\
Caterpillar & 0.100 & 0.094 \\
Chevron & 0.084 & 0.047 \\
Coca-Cola & 0.099 & 0.094 \\
Walt Disney & 0.103 & 0.044 \\
Exxon & 0.072 & 0.049 \\
GE & 0.052 & 0.048 \\
Home Depot & 0.190 & 0.143 \\
IBM & 0.055 & 0.032 \\
Intel & 0.133 & 0.057 \\
Johnson \& Johnson & 0.113 & 0.081 \\
JP Morgan & 0.090 & 0.045 \\
McDonalds & 0.114 & 0.079 \\
Merck & 0.063 & 0.080 \\
Microsoft & 0.180 & 0.094 \\
Nike & 0.177 & 0.141 \\
Pfizer & 0.097 & 0.099 \\
Procter \& Gamble & 0.095 & 0.039 \\
Travellers & 0.082 & 0.068 \\
United Technologies & 0.113 & 0.056 \\
United Health Group & 0.252 & 0.152 \\
Verizon & 0.043 & 0.048 \\
Wal-Mart & 0.113 & 0.093 \\
Cisco & 0.210 & 0.225 \\
Goldman Sachs & 0.061 & 0.053 \\
Visa & 0.236 & 0.217 \\
Average & $\mathbf{0 . 1 1 7}$ & $\mathbf{0 . 0 8 8}$ \\
& & \\
\hline & &
\end{tabular}




\section{Appendix 2}

Table 8: Annualized daily volatility of MA40-MA200, average annualized volatility

\begin{tabular}{|c|c|c|c|c|c|c|c|c|c|c|c|}
\hline & $\begin{array}{c}\text { Buy } \\
\text { \& }\end{array}$ & & & & & & & & & & \\
\hline & Hold & MA200 & MA180 & MA160 & MA140 & MA120 & MA100 & MA80 & MA60 & MA40 & \\
\hline $3 M$ & 0.225 & 0.164 & 0.165 & 0.161 & 0.161 & 0.159 & 0.159 & 0.158 & 0.158 & 0.157 & \\
\hline American Express & 0.345 & 0.227 & 0.228 & 0.221 & 0.225 & 0.224 & 0.225 & 0.224 & 0.228 & 0.229 & \\
\hline Apple & 0.451 & 0.317 & 0.321 & 0.315 & 0.315 & 0.313 & 0.315 & 0.315 & 0.310 & 0.305 & \\
\hline Boeing & 0.294 & 0.201 & 0.203 & 0.199 & 0.201 & 0.199 & 0.198 & 0.198 & 0.201 & 0.204 & \\
\hline Caterpillar & 0.311 & 0.216 & 0.218 & 0.216 & 0.216 & 0.214 & 0.215 & 0.214 & 0.213 & 0.215 & \\
\hline Chevron & 0.244 & 0.167 & 0.168 & 0.166 & 0.166 & 0.166 & 0.165 & 0.164 & 0.167 & 0.168 & \\
\hline Coca-Cola & 0.225 & 0.164 & 0.166 & 0.161 & 0.160 & 0.159 & 0.158 & 0.158 & 0.156 & 0.155 & \\
\hline Walt Disney & 0.291 & 0.196 & 0.201 & 0.199 & 0.200 & 0.199 & 0.198 & 0.203 & 0.204 & 0.203 & \\
\hline Exxon & 0.230 & 0.162 & 0.163 & 0.159 & 0.159 & 0.159 & 0.157 & 0.156 & 0.155 & 0.157 & \\
\hline GE & 0.275 & 0.174 & 0.175 & 0.172 & 0.173 & 0.173 & 0.171 & 0.168 & 0.168 & 0.168 & \\
\hline Home Depot & 0.314 & 0.226 & 0.228 & 0.223 & 0.221 & 0.221 & 0.219 & 0.217 & 0.217 & 0.214 & \\
\hline IBM & 0.271 & 0.187 & 0.189 & 0.185 & 0.184 & 0.181 & 0.179 & 0.177 & 0.176 & 0.174 & \\
\hline Intel & 0.382 & 0.273 & 0.275 & 0.267 & 0.265 & 0.263 & 0.260 & 0.257 & 0.256 & 0.254 & \\
\hline Johnson \& Johnson & 0.215 & 0.163 & 0.164 & 0.161 & 0.159 & 0.157 & 0.155 & 0.153 & 0.152 & 0.149 & \\
\hline JP Morgan & 0.375 & 0.223 & 0.226 & 0.223 & 0.224 & 0.227 & 0.237 & 0.242 & 0.245 & 0.248 & \\
\hline McDonalds & 0.240 & 0.183 & 0.184 & 0.18 & 0.178 & 0.177 & 0.176 & 0.176 & 0.175 & 0.174 & \\
\hline Merck & 0.269 & 0.177 & 0.179 & 0.173 & 0.173 & 0.174 & 0.172 & 0.174 & 0.174 & 0.177 & \\
\hline Microsoft & 0.323 & 0.248 & 0.249 & 0.243 & 0.241 & 0.237 & 0.236 & 0.233 & 0.232 & 0.231 & \\
\hline Nike & 0.327 & 0.243 & 0.245 & 0.238 & 0.236 & 0.235 & 0.235 & 0.232 & 0.232 & 0.233 & \\
\hline Pfizer & 0.266 & 0.188 & 0.19 & 0.187 & 0.186 & 0.187 & 0.186 & 0.187 & 0.187 & 0.187 & \\
\hline Procter \& Gamble & 0.225 & 0.169 & 0.169 & 0.164 & 0.163 & 0.161 & 0.158 & 0.157 & 0.156 & 0.156 & \\
\hline Travellers & 0.268 & 0.174 & 0.175 & 0.174 & 0.175 & 0.178 & 0.180 & 0.184 & 0.182 & 0.185 & \\
\hline United Technologies & 0.261 & 0.179 & 0.181 & 0.179 & 0.178 & 0.177 & 0.177 & 0.177 & 0.176 & 0.173 & \\
\hline United Health Group & 0.386 & 0.290 & 0.293 & 0.290 & 0.290 & 0.283 & 0.282 & 0.282 & 0.280 & 0.273 & \\
\hline Verizon & 0.246 & 0.163 & 0.165 & 0.164 & 0.163 & 0.163 & 0.163 & 0.161 & 0.161 & 0.163 & \\
\hline Wal-Mart & 0.263 & 0.203 & 0.204 & 0.200 & 0.198 & 0.195 & 0.191 & 0.19 & 0.189 & 0.191 & \\
\hline Cisco & 0.415 & 0.300 & 0.302 & 0.297 & 0.295 & 0.291 & 0.290 & 0.285 & 0.282 & 0.275 & \\
\hline Goldman Sachs & 0.373 & 0.222 & 0.226 & 0.22 & 0.222 & 0.223 & 0.228 & 0.230 & 0.227 & 0.229 & \\
\hline Visa & 0.260 & 0.209 & 0.212 & 0.209 & 0.208 & 0.212 & 0.208 & 0.206 & 0.205 & 0.197 & \\
\hline Average & 0.295 & 0.207 & 0.209 & 0.205 & 0.205 & 0.204 & 0.203 & 0.203 & 0.202 & 0.202 & 204 \\
\hline
\end{tabular}


Table 9: Annualized daily (every fifth trading day) volatility of MAW8-MAW40

( $W$ = number of weeks), average annualized volatility

$3 \mathrm{M}$

American Express

Apple

Boeing

Caterpillar

Chevron

Coca-Cola

Walt Disney

Exxon

GE

Home Depot

IBM

Intel

Johnson \& Johnson

JP Morgan

McDonalds

Merck

Microsoft

Nike

Pfizer

Procter \& Gamble

Travellers

United Technologies

United Health Group

Verizon

Wal-Mart

Cisco

Goldman Sachs

Visa

Average

\begin{tabular}{|c|c|c|c|c|c|c|c|c|c|}
\hline 0.225 & 0.165 & 0.165 & 0.163 & 0.163 & 0.16 & 0.159 & 0.157 & 0.157 & 0.159 \\
\hline 0.345 & 0.227 & 0.224 & 0.224 & 0.227 & 0.225 & 0.223 & 0.228 & 0.232 & 0.234 \\
\hline 0.451 & 0.316 & 0.316 & 0.313 & 0.318 & 0.316 & 0.343 & 0.317 & 0.312 & 0.309 \\
\hline 0.294 & 0.204 & 0.203 & 0.204 & 0.204 & 0.203 & 0.203 & 0.201 & 0.201 & 0.206 \\
\hline 0.311 & 0.216 & 0.215 & 0.215 & 0.217 & 0.214 & 0.215 & 0.215 & 0.213 & 0.214 \\
\hline 0.244 & 0.169 & 0.168 & 0.169 & 0.168 & 0.168 & 0.167 & 0.166 & 0.168 & 0.172 \\
\hline 0.225 & 0.165 & 0.165 & 0.164 & 0.162 & 0.160 & 0.159 & 0.159 & 0.157 & 0.155 \\
\hline 0.291 & 0.195 & 0.198 & 0.197 & 0.197 & 0.199 & 0.200 & 0.202 & 0.203 & 0.204 \\
\hline 0.230 & 0.163 & 0.161 & 0.160 & 0.161 & 0.160 & 0.157 & 0.156 & 0.153 & 0.158 \\
\hline 0.275 & 0.174 & 0.174 & 0.174 & 0.175 & 0.174 & 0.170 & 0.169 & 0.171 & 0.166 \\
\hline 0.314 & 0.228 & 0.228 & 0.226 & 0.225 & 0.222 & 0.224 & 0.219 & 0.219 & 0.214 \\
\hline 0.271 & 0.190 & 0.188 & 0.185 & 0.184 & 0.183 & 0.178 & 0.177 & 0.178 & 0.177 \\
\hline 0.382 & 0.267 & 0.267 & 0.268 & 0.264 & 0.263 & 0.259 & 0.256 & 0.259 & 0.259 \\
\hline 0.215 & 0.164 & 0.163 & 0.162 & 0.160 & 0.158 & 0.156 & 0.156 & 0.152 & 0.15 \\
\hline 0.375 & 0.222 & 0.225 & 0.224 & 0.230 & 0.236 & 0.239 & 0.243 & 0.241 & 0.252 \\
\hline 0.240 & 0.185 & 0.182 & 0.181 & 0.179 & 0.177 & 0.177 & 0.176 & 0.174 & 0.171 \\
\hline 0.269 & 0.179 & 0.175 & 0.174 & 0.173 & 0.173 & 0.172 & 0.175 & 0.176 & 0.175 \\
\hline 0.323 & 0.250 & 0.247 & 0.245 & 0.244 & 0.24 & 0.236 & 0.236 & 0.230 & 0.232 \\
\hline 0.327 & 0.244 & 0.241 & 0.239 & 0.240 & 0.241 & 0.238 & 0.235 & 0.232 & 0.232 \\
\hline 0.266 & 0.189 & 0.187 & 0.186 & 0.187 & 0.188 & 0.190 & 0.189 & 0.189 & 0.184 \\
\hline 0.225 & 0.170 & 0.168 & 0.167 & 0.165 & 0.164 & 0.161 & 0.158 & 0.160 & 0.156 \\
\hline 0.268 & 0.175 & 0.175 & 0.175 & 0.178 & 0.177 & 0.177 & 0.184 & 0.184 & 0.185 \\
\hline 0.261 & 0.181 & 0.179 & 0.178 & 0.177 & 0.177 & 0.177 & 0.177 & 0.176 & 0.172 \\
\hline 0.386 & 0.292 & 0.291 & 0.292 & 0.291 & 0.290 & 0.289 & 0.287 & 0.282 & 0.278 \\
\hline 0.246 & 0.163 & 0.162 & 0.162 & 0.162 & 0.164 & 0.162 & 0.161 & 0.160 & 0.159 \\
\hline 0.263 & 0.205 & 0.202 & 0.201 & 0.198 & 0.194 & 0.191 & 0.191 & 0.190 & 0.192 \\
\hline 0.415 & 0.307 & 0.305 & 0.300 & 0.296 & 0.292 & 0.293 & 0.288 & 0.285 & 0.281 \\
\hline 0.373 & 0.225 & 0.223 & 0.221 & 0.221 & 0.220 & 0.230 & 0.233 & 0.241 & 0.241 \\
\hline 0.260 & 0.203 & 0.210 & 0.209 & 0.208 & 0.210 & 0.208 & 0.206 & 0.203 & 0.195 \\
\hline 0.295 & 0.208 & 0.207 & 0.206 & 0.206 & 0.205 & 0.205 & 0.204 & 0.203 & 0.203 \\
\hline
\end{tabular}


Table 10: Annualized daily (rule in every 20s trading day) volatility of MA2MA10, average annualized volatility

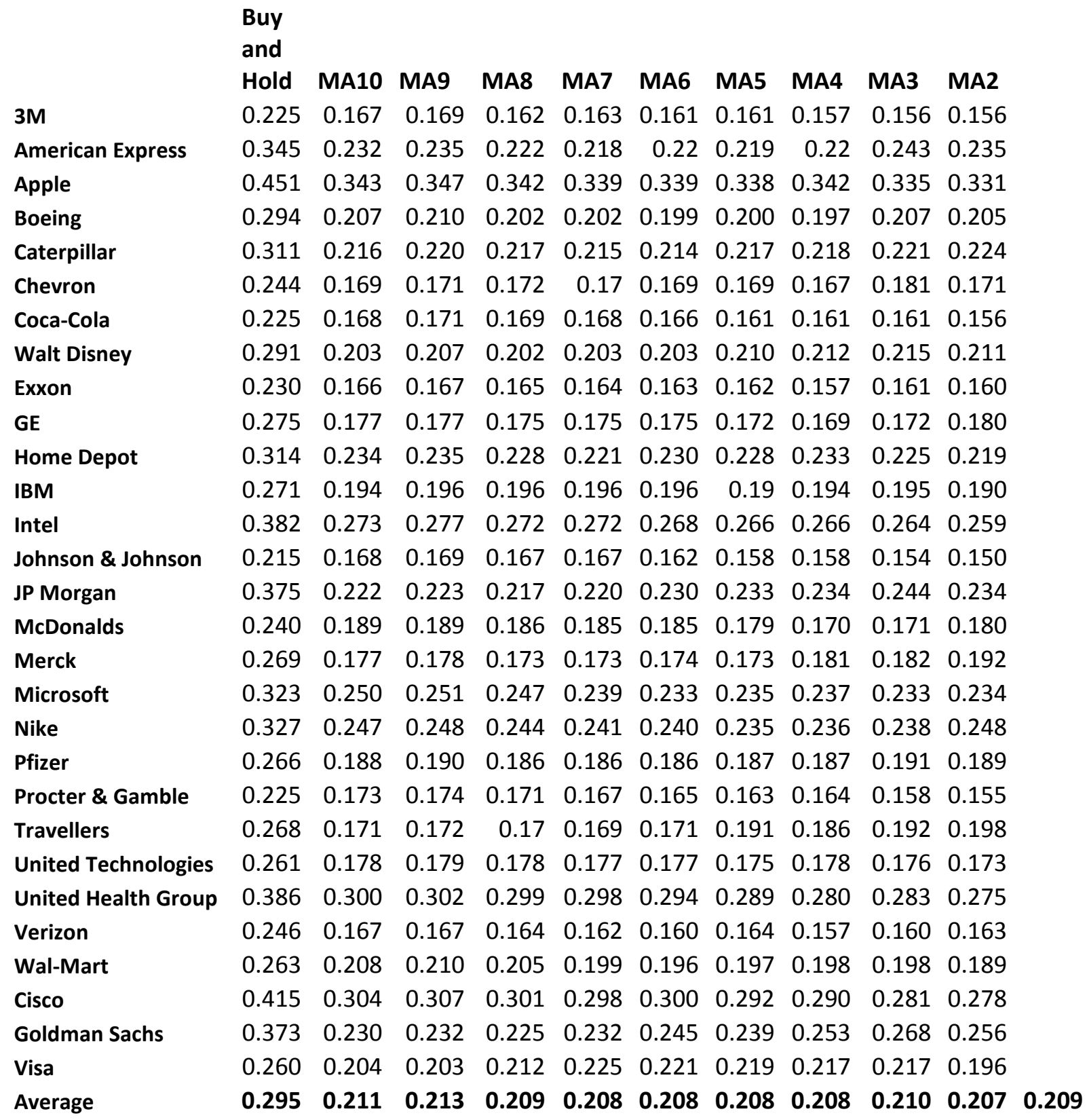


Table 11: Annualized daily (every other month) volatility of MAD2-MAD2 (D = every other month, and 5,4,3,2 are the numbers of observations in the rolling window), average annualized volatility

\begin{tabular}{|c|c|c|c|c|c|}
\hline & Buy\&Hold & MAD5 & MAD4 & MAD3 & MAD2 \\
\hline $3 M$ & 0.225 & 0.168 & 0.169 & 0.162 & 0.159 \\
\hline American Express & 0.344 & 0.222 & 0.226 & 0.216 & 0.211 \\
\hline Apple & 0.450 & 0.351 & 0.363 & 0.357 & 0.338 \\
\hline Boeing & 0.294 & 0.210 & 0.216 & 0.211 & 0.208 \\
\hline Caterpillar & 0.311 & 0.218 & 0.229 & 0.215 & 0.211 \\
\hline Chevron & 0.244 & 0.168 & 0.175 & 0.166 & 0.165 \\
\hline Coca-Cola & 0.225 & 0.168 & 0.173 & 0.165 & 0.158 \\
\hline Walt Disney & 0.291 & 0.197 & 0.200 & 0.198 & 0.203 \\
\hline Exxon & 0.230 & 0.172 & 0.174 & 0.159 & 0.156 \\
\hline GE & 0.274 & 0.175 & 0.181 & 0.176 & 0.182 \\
\hline Home Depot & 0.314 & 0.229 & 0.230 & 0.221 & 0.237 \\
\hline IBM & 0.271 & 0.196 & 0.199 & 0.200 & 0.200 \\
\hline Intel & 0.382 & 0.274 & 0.286 & 0.267 & 0.265 \\
\hline Johnson \& Johnson & 0.215 & 0.173 & 0.175 & 0.165 & 0.154 \\
\hline JP Morgan & 0.375 & 0.236 & 0.241 & 0.246 & 0.237 \\
\hline McDonalds & 0.240 & 0.182 & 0.186 & 0.178 & 0.169 \\
\hline Merck & 0.269 & 0.185 & 0.196 & 0.188 & 0.199 \\
\hline Microsoft & 0.323 & 0.245 & 0.249 & 0.238 & 0.250 \\
\hline Nike & 0.327 & 0.252 & 0.258 & 0.253 & 0.253 \\
\hline Pfizer & 0.266 & 0.199 & 0.203 & 0.191 & 0.189 \\
\hline Procter \& Gamble & 0.225 & 0.173 & 0.177 & 0.169 & 0.166 \\
\hline Travellers & 0.268 & 0.176 & 0.178 & 0.183 & 0.191 \\
\hline United Technologies & 0.261 & 0.182 & 0.187 & 0.178 & 0.177 \\
\hline United Health Group & 0.386 & 0.313 & 0.313 & 0.299 & 0.305 \\
\hline Verizon & 0.246 & 0.163 & 0.171 & 0.165 & 0.153 \\
\hline Wal-Mart & 0.263 & 0.197 & 0.199 & 0.194 & 0.193 \\
\hline Cisco & 0.415 & 0.312 & 0.317 & 0.315 & 0.285 \\
\hline Goldman Sachs & 0.373 & 0.229 & 0.245 & 0.239 & 0.265 \\
\hline Visa & 0.260 & 0.215 & 0.215 & 0.225 & 0.222 \\
\hline Average & 0.295 & 0.213 & 0.218 & 0.212 & 0.210 \\
\hline
\end{tabular}


Table 12: Annualized daily (every third month) volatility of MAT2-MAT4 (T = every third month, and 4,3,2 are the numbers of observations in the rolling window), average annualized volatility

$\begin{array}{lcccc} & \text { Buy\&Hold } & \text { MAT4 } & \text { MAT3 } & \text { MAT2 } \\ \text { 3M } & 0.225 & 0.172 & 0.174 & 0.171 \\ \text { American Express } & 0.344 & 0.230 & 0.237 & 0.206 \\ \text { Apple } & 0.450 & 0.345 & 0.357 & 0.349 \\ \text { Boeing } & 0.294 & 0.206 & 0.219 & 0.200 \\ \text { Caterpillar } & 0.311 & 0.219 & 0.223 & 0.214 \\ \text { Chevron } & 0.244 & 0.176 & 0.182 & 0.170 \\ \text { Coca-Cola } & 0.225 & 0.177 & 0.179 & 0.181 \\ \text { Walt Disney } & 0.291 & 0.220 & 0.228 & 0.205 \\ \text { Exxon } & 0.230 & 0.168 & 0.176 & 0.158 \\ \text { GE } & 0.274 & 0.178 & 0.185 & 0.177 \\ \text { Home Depot } & 0.314 & 0.236 & 0.251 & 0.241 \\ \text { IBM } & 0.271 & 0.205 & 0.209 & 0.193 \\ \text { Intel } & 0.382 & 0.285 & 0.296 & 0.274 \\ \text { Johnson \& Johnson } & 0.215 & 0.185 & 0.188 & 0.165 \\ \text { JP Morgan } & 0.375 & 0.242 & 0.248 & 0.240 \\ \text { McDonalds } & 0.240 & 0.198 & 0.204 & 0.192 \\ \text { Merck } & 0.269 & 0.191 & 0.191 & 0.180 \\ \text { Microsoft } & 0.323 & 0.257 & 0.267 & 0.258 \\ \text { Nike } & 0.327 & 0.264 & 0.265 & 0.258 \\ \text { Pfizer } & 0.266 & 0.195 & 0.206 & 0.208 \\ \text { Procter \& Gamble } & 0.225 & 0.177 & 0.181 & 0.168 \\ \text { Travellers } & 0.268 & 0.187 & 0.188 & 0.198 \\ \text { United Technologies } & 0.261 & 0.192 & 0.199 & 0.187 \\ \text { United Health Group } & 0.386 & 0.300 & 0.308 & 0.315 \\ \text { Verizon } & 0.246 & 0.176 & 0.176 & 0.160 \\ \text { Wal-Mart } & 0.263 & 0.202 & 0.208 & 0.208 \\ \text { Cisco } & 0.415 & 0.310 & 0.311 & 0.303 \\ \text { Goldman Sachs } & 0.373 & 0.226 & 0.232 & 0.235 \\ \text { Visa } & 0.260 & 0.204 & 0.215 & 0.208 \\ \text { Average } & \mathbf{0 . 2 9 5} & \mathbf{0 . 2 1 8} & \mathbf{0 . 2 2 4} & \mathbf{0 . 2 1 4}\end{array}$


Table 13: Annualized daily (every fourth month) volatility of MAQ2-MAQ3 (Q = every fourth month, 3 and 2 are the number of observations in the rolling window), average annualized volatility

$\begin{array}{lcll} & \text { Buy\&Hold } & \text { MAQ3 } & \text { MAQ3 } \\ \text { 3M } & 0.225 & 0.168 & 0.176 \\ \text { American Express } & 0.344 & 0.220 & 0.226 \\ \text { Apple } & 0.450 & 0.360 & 0.373 \\ \text { Boeing } & 0.294 & 0.213 & 0.224 \\ \text { Caterpillar } & 0.311 & 0.222 & 0.239 \\ \text { Chevron } & 0.244 & 0.167 & 0.177 \\ \text { Coca-Cola } & 0.225 & 0.173 & 0.182 \\ \text { Walt Disney } & 0.291 & 0.206 & 0.218 \\ \text { Exxon } & 0.230 & 0.160 & 0.176 \\ \text { GE } & 0.274 & 0.180 & 0.195 \\ \text { Home Depot } & 0.314 & 0.237 & 0.242 \\ \text { IBM } & 0.271 & 0.194 & 0.218 \\ \text { Intel } & 0.382 & 0.274 & 0.293 \\ \text { Johnson \& Johnson } & 0.215 & 0.181 & 0.186 \\ \text { JP Morgan } & 0.375 & 0.218 & 0.227 \\ \text { McDonalds } & 0.240 & 0.177 & 0.193 \\ \text { Merck } & 0.269 & 0.204 & 0.212 \\ \text { Microsoft } & 0.323 & 0.248 & 0.260 \\ \text { Nike } & 0.327 & 0.258 & 0.265 \\ \text { Pfizer } & 0.266 & 0.198 & 0.207 \\ \text { Procter \& Gamble } & 0.225 & 0.173 & 0.174 \\ \text { Travellers } & 0.268 & 0.182 & 0.192 \\ \text { United Technologies } & 0.261 & 0.181 & 0.188 \\ \text { United Health Group } & 0.386 & 0.299 & 0.314 \\ \text { Verizon } & 0.246 & 0.167 & 0.177 \\ \text { Wal-Mart } & 0.263 & 0.194 & 0.207 \\ \text { Cisco } & 0.415 & 0.341 & 0.349 \\ \text { Goldman Sachs } & 0.373 & 0.240 & 0.260 \\ \text { Visa } & 0.260 & 0.212 & 0.225 \\ \text { Average } & \mathbf{0 . 2 9 5} & \mathbf{0 . 2 1 5} & \mathbf{0 . 2 2 7} \\ & & & \mathbf{0 . 2 2 1}\end{array}$


Table 14: Annualized daily (every fifth month) volatility of MAC2 (C = every fifth month, 2 = observations in rolling window), average annualized volatility

$\begin{array}{lcc} & \text { Buy \& Hold } & \text { MAC2 } \\ \text { 3M } & 0.225 & 0.176 \\ \text { American Express } & 0.344 & 0.226 \\ \text { Apple } & 0.450 & 0.323 \\ \text { Boeing } & 0.294 & 0.218 \\ \text { Caterpillar } & 0.311 & 0.227 \\ \text { Chevron } & 0.244 & 0.165 \\ \text { Coca-Cola } & 0.225 & 0.168 \\ \text { Walt Disney } & 0.291 & 0.206 \\ \text { Exxon } & 0.230 & 0.166 \\ \text { GE } & 0.274 & 0.187 \\ \text { Home Depot } & 0.314 & 0.242 \\ \text { IBM } & 0.271 & 0.202 \\ \text { Intel } & 0.382 & 0.296 \\ \text { Johnson \& Johnson } & 0.215 & 0.187 \\ \text { JP Morgan } & 0.375 & 0.244 \\ \text { McDonalds } & 0.240 & 0.182 \\ \text { Merck } & 0.269 & 0.194 \\ \text { Microsoft } & 0.323 & 0.250 \\ \text { Nike } & 0.327 & 0.249 \\ \text { Pfizer } & 0.266 & 0.191 \\ \text { Procter \& Gamble } & 0.225 & 0.187 \\ \text { Travellers } & 0.268 & 0.183 \\ \text { United Technologies } & 0.261 & 0.204 \\ \text { United Health Group } & 0.386 & 0.298 \\ \text { Verizon } & 0.246 & 0.170 \\ \text { Wal-Mart } & 0.263 & 0.223 \\ \text { Cisco } & 0.415 & 0.333 \\ \text { Goldman Sachs } & 0.373 & 0.218 \\ \text { Visa } & 0.260 & 0.220 \\ \text { Average } & \mathbf{0 . 2 9 5} & \mathbf{0 . 2 1 8}\end{array}$




\section{Appendix 3}

Table 15: Transaction costs per year of MA40-MA200, with one transaction costing $0.1 \%$ of total wealth, average annualized transaction costs

\begin{tabular}{|c|c|c|c|c|c|c|c|c|c|}
\hline & MA200 & MA180 & MA160 & MA140 & MA120 & MA100 & MA80 & MA60 & MA40 \\
\hline 3M & 0.010 & 0.011 & 0.010 & 0.011 & 0.012 & 0.013 & 0.016 & 0.019 & 0.022 \\
\hline American Express & 0.011 & 0.011 & 0.011 & 0.012 & 0.012 & 0.013 & 0.016 & 0.017 & 0.023 \\
\hline Apple & 0.007 & 0.008 & 0.008 & 0.009 & 0.010 & 0.012 & 0.014 & 0.015 & 0.020 \\
\hline Boeing & 0.008 & 0.009 & 0.010 & 0.011 & 0.011 & 0.012 & 0.014 & 0.015 & 0.020 \\
\hline Caterpillar & 0.008 & 0.009 & 0.010 & 0.011 & 0.012 & 0.013 & 0.015 & 0.015 & 0.019 \\
\hline Chevron & 0.011 & 0.012 & 0.012 & 0.013 & 0.014 & 0.016 & 0.018 & 0.020 & 0.024 \\
\hline Coca-Cola & 0.009 & 0.010 & 0.011 & 0.011 & 0.011 & 0.012 & 0.015 & 0.018 & 0.022 \\
\hline Walt Disney & 0.007 & 0.008 & 0.009 & 0.011 & 0.012 & 0.012 & 0.013 & 0.017 & 0.021 \\
\hline Exxon & 0.011 & 0.013 & 0.016 & 0.017 & 0.017 & 0.018 & 0.019 & 0.023 & 0.028 \\
\hline GE & 0.007 & 0.008 & 0.009 & 0.010 & 0.011 & 0.012 & 0.014 & 0.017 & 0.023 \\
\hline Home Depot & 0.008 & 0.009 & 0.010 & 0.011 & 0.013 & 0.014 & 0.016 & 0.018 & 0.021 \\
\hline IBM & 0.009 & 0.010 & 0.010 & 0.010 & 0.012 & 0.012 & 0.013 & 0.014 & 0.019 \\
\hline Intel & 0.007 & 0.009 & 0.010 & 0.010 & 0.012 & 0.014 & 0.014 & 0.016 & 0.019 \\
\hline Johnson \& Johnson & 0.009 & 0.008 & 0.009 & 0.010 & 0.012 & 0.014 & 0.016 & 0.020 & 0.024 \\
\hline JP Morgan & 0.010 & 0.010 & 0.011 & 0.012 & 0.012 & 0.014 & 0.015 & 0.016 & 0.020 \\
\hline McDonalds & 0.010 & 0.011 & 0.011 & 0.013 & 0.012 & 0.014 & 0.016 & 0.018 & 0.023 \\
\hline Merck & 0.008 & 0.009 & 0.009 & 0.011 & 0.011 & 0.013 & 0.015 & 0.017 & 0.022 \\
\hline Microsoft & 0.008 & 0.009 & 0.010 & 0.010 & 0.011 & 0.013 & 0.015 & 0.015 & 0.020 \\
\hline Nike & 0.009 & 0.009 & 0.010 & 0.010 & 0.011 & 0.012 & 0.013 & 0.014 & 0.019 \\
\hline Pfizer & 0.008 & 0.010 & 0.010 & 0.011 & 0.011 & 0.012 & 0.014 & 0.017 & 0.021 \\
\hline Procter \& Gamble & 0.010 & 0.010 & 0.010 & 0.011 & 0.012 & 0.014 & 0.016 & 0.019 & 0.022 \\
\hline Travellers & 0.010 & 0.011 & 0.012 & 0.012 & 0.013 & 0.015 & 0.016 & 0.018 & 0.024 \\
\hline United Technologies & 0.009 & 0.010 & 0.011 & 0.011 & 0.012 & 0.014 & 0.015 & 0.018 & 0.021 \\
\hline United Health Group & 0.008 & 0.008 & 0.010 & 0.010 & 0.011 & 0.012 & 0.014 & 0.017 & 0.021 \\
\hline Verizon & 0.011 & 0.011 & 0.011 & 0.011 & 0.013 & 0.014 & 0.017 & 0.018 & 0.023 \\
\hline Wal-Mart & 0.010 & 0.010 & 0.012 & 0.013 & 0.013 & 0.014 & 0.015 & 0.019 & 0.022 \\
\hline Cisco & 0.006 & 0.006 & 0.008 & 0.010 & 0.009 & 0.010 & 0.014 & 0.017 & 0.023 \\
\hline Goldman Sachs & 0.008 & 0.010 & 0.012 & 0.012 & 0.014 & 0.015 & 0.022 & 0.026 & 0.035 \\
\hline Visa & 0.008 & 0.008 & 0.009 & 0.009 & 0.008 & 0.010 & 0.011 & 0.014 & 0.022 \\
\hline Average & 0.009 & 0.0010 & 0.010 & 0.011 & 0.012 & 0.013 & 0.015 & 0.018 & 0.022 \\
\hline
\end{tabular}


Table 16: Transaction costs per year of MA2-MA10, average annualized transaction costs

\begin{tabular}{|c|c|c|c|c|c|c|c|c|c|}
\hline & MA10 & MA9 & MA8 & MA7 & MA6 & MA5 & MA4 & MA3 & MA2 \\
\hline 3M & 0.003 & 0.003 & 0.003 & 0.003 & 0.003 & 0.004 & 0.004 & 0.005 & 0.006 \\
\hline American Express & 0.002 & 0.002 & 0.002 & 0.002 & 0.002 & 0.003 & 0.003 & 0.004 & 0.006 \\
\hline Apple & 0.002 & 0.002 & 0.002 & 0.002 & 0.003 & 0.003 & 0.004 & 0.005 & 0.006 \\
\hline Boeing & 0.002 & 0.002 & 0.002 & 0.002 & 0.002 & 0.003 & 0.004 & 0.004 & 0.006 \\
\hline Caterpillar & 0.002 & 0.002 & 0.002 & 0.002 & 0.003 & 0.003 & 0.004 & 0.005 & 0.006 \\
\hline Chevron & 0.002 & 0.003 & 0.003 & 0.003 & 0.003 & 0.003 & 0.004 & 0.005 & 0.007 \\
\hline Coca-Cola & 0.002 & 0.002 & 0.002 & 0.002 & 0.002 & 0.003 & 0.003 & 0.004 & 0.006 \\
\hline Walt Disney & 0.002 & 0.002 & 0.002 & 0.002 & 0.003 & 0.003 & 0.003 & 0.004 & 0.006 \\
\hline Exxon & 0.002 & 0.002 & 0.003 & 0.003 & 0.003 & 0.004 & 0.004 & 0.005 & 0.006 \\
\hline GE & 0.002 & 0.002 & 0.002 & 0.002 & 0.003 & 0.003 & 0.004 & 0.004 & 0.006 \\
\hline Home Depot & 0.002 & 0.002 & 0.002 & 0.002 & 0.003 & 0.003 & 0.003 & 0.004 & 0.006 \\
\hline IBM & 0.003 & 0.002 & 0.003 & 0.002 & 0.003 & 0.003 & 0.004 & 0.004 & 0.006 \\
\hline Intel & 0.002 & 0.003 & 0.003 & 0.003 & 0.003 & 0.003 & 0.004 & 0.004 & 0.006 \\
\hline Johnson \& Johnson & 0.002 & 0.002 & 0.002 & 0.002 & 0.003 & 0.003 & 0.004 & 0.005 & 0.006 \\
\hline JP Morgan & 0.002 & 0.003 & 0.003 & 0.003 & 0.003 & 0.003 & 0.003 & 0.004 & 0.006 \\
\hline McDonalds & 0.002 & 0.002 & 0.003 & 0.003 & 0.003 & 0.003 & 0.004 & 0.005 & 0.006 \\
\hline Merck & 0.002 & 0.002 & 0.002 & 0.003 & 0.003 & 0.003 & 0.004 & 0.005 & 0.006 \\
\hline Microsoft & 0.002 & 0.002 & 0.002 & 0.003 & 0.003 & 0.003 & 0.004 & 0.004 & 0.006 \\
\hline Nike & 0.002 & 0.002 & 0.002 & 0.002 & 0.003 & 0.003 & 0.004 & 0.004 & 0.006 \\
\hline Pfizer & 0.002 & 0.002 & 0.002 & 0.003 & 0.003 & 0.003 & 0.004 & 0.004 & 0.006 \\
\hline Procter \& Gamble & 0.002 & 0.002 & 0.003 & 0.003 & 0.003 & 0.004 & 0.004 & 0.005 & 0.006 \\
\hline Travellers & 0.003 & 0.002 & 0.003 & 0.003 & 0.003 & 0.004 & 0.004 & 0.005 & 0.007 \\
\hline United Technologies & 0.002 & 0.002 & 0.002 & 0.002 & 0.003 & 0.003 & 0.004 & 0.004 & 0.006 \\
\hline United Health Group & 0.002 & 0.002 & 0.002 & 0.003 & 0.003 & 0.003 & 0.003 & 0.004 & 0.006 \\
\hline Verizon & 0.003 & 0.003 & 0.003 & 0.003 & 0.003 & 0.004 & 0.004 & 0.005 & 0.006 \\
\hline Wal-Mart & 0.003 & 0.003 & 0.003 & 0.003 & 0.003 & 0.004 & 0.004 & 0.005 & 0.006 \\
\hline Cisco & 0.002 & 0.002 & 0.002 & 0.002 & 0.003 & 0.003 & 0.003 & 0.005 & 0.006 \\
\hline Goldman Sachs & 0.002 & 0.002 & 0.002 & 0.003 & 0.003 & 0.003 & 0.003 & 0.004 & 0.005 \\
\hline Visa & 0.002 & 0.001 & 0.002 & 0.002 & 0.002 & 0.003 & 0.003 & 0.003 & 0.005 \\
\hline Average & 0.002 & 0.002 & 0.002 & 0.003 & 0.003 & 0.003 & 0.004 & 0.004 & 0.006 \\
\hline
\end{tabular}

